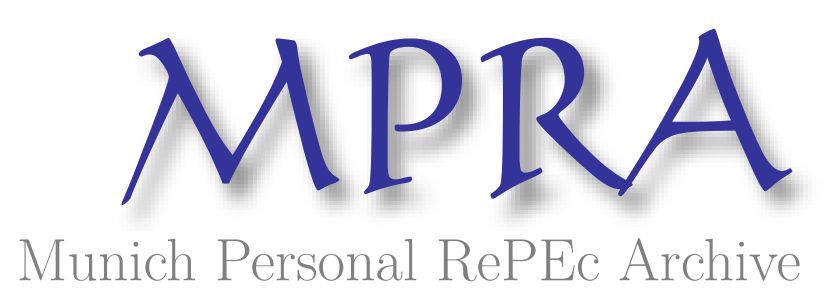

\title{
A Small Open Economy DSGE Model for Pakistan
}

Haider, Adnan and Khan, Safdar Ullah

Research Department, State Bank of Pakistan

6 November 2008

Online at https://mpra.ub.uni-muenchen.de/12977/

MPRA Paper No. 12977, posted 24 Jan 2009 08:50 UTC 


\section{A Small Open Economy DSGE Model for Pakistan}

Adnan Haider, Safdar Ullah khan

Research Department

State Bank of Pakistan

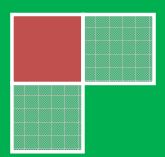




\title{
A Small Open Economy DSGE Model for Pakistan
}

\author{
† Adnan Haider \\ Economic Modeling Division \\ Research Department \\ State Bank of Pakistan \\ adnan.haider@sbp.org.pk
}

\author{
Safdar Ullah Khan \\ Faculty of Business, Technology and \\ Sustainable Development, \\ Bond University Australia \\ skhan@bond.edu.au
}

\begin{abstract}
This paper estimates a small open economy Dynamic Stochastic General Equilibrium (DSGE) model for Pakistan using Bayesian simulation approach. Model setup is based on new Keynesian framework, characterized by nominal rigidity in prices with habit formation in household's consumption. The core objective is to study whether an estimated small open economy DSGE model provides a realistic behavior about the structure Pakistan economy with fully articulated description of the monetary policy transmission mechanism vis-à-vis domestic firm's price setting behavior. To do so, we analyze the impulse responses of key macro variables; domestic inflation, imported inflation, output, consumption, interest rate, exchange rate, term of trade to different structural/exogenous shocks. From several interesting results, few are; (a) high inflation in Pakistan do not hit domestic consumption significantly; (b) Central bank of Pakistan responds to high inflation by increasing the policy rate by 100 to 200 bps; (c) exchange rate appreciates in both the cases of high domestic and imported inflation; (d) tight monetary policy stance helps to curb domestic inflation as well as imported inflation but appreciates exchange rate significantly (f) pass through of exchange rate to domestic inflation is very low; finally parameter value of domestic price stickiness shows that around 24 percent domestic firms do not re-optimize their prices which implies averaged price contract is about two quarters.
\end{abstract}

JEL Classifications: E32, E47, E52, F37, F47

Keywords: New-Keynesian economics, open economy DSGE models, nominal rigidities, monetary policy transmission mechanism, Bayesian Approach

Revised Version: January 2009

\footnotetext{
${ }^{\dagger}$ Corresponding Author- Views expressed here are those of the authors and not necessarily of the State Bank of Pakistan or Bond University, Australia. Any errors or omissions in this paper are the responsibility of the authors.

Acknowledgement: The authors are grateful to M. Ali Choudhary for his insightful comments on the earlier draft of this paper. They are also thankful to Macro Ratto, Martin Melecky, Nikolay Iskrev, Philip Liu, Rafael Wouters and Zulfiqar Hyder for their support, guidance and helpful discussions.
} 
The complex nature of DSGE models may have also limited their acceptance among policy makers, as notation can get very messy, thus creating a natural barrier for the communication of the results to policy makers, not to mention to the public. Furthermore, understanding the working of these models requires well trained macroeconomists with a modeling culture and strong statistical and computer programming skills. This also implies that central banks may need to invest additional resources to develop such models, something that might not always be considered as priority or simply resources might be scarce.

Camilo E. Tovar (2008)

\section{Introduction}

In recent years there has been a growing interest in academics, international policy institutions and central banks ${ }^{1}$ in developing small-to-medium, even large-scale, open economy macroeconomic models called Dynamic Stochastic General Equilibrium (DSGE) models based on new-Keynesian framework. ${ }^{2}$ The term DSGE was originally used by Kydland and Prescott (1982) in their seminal contribution on Real Business Cycle (RBC) model. The RBC model is based on neoclassical framework with micro-founded optimization behavior of economic agents with flexible prices. One of the critical assumptions of this model is that fluctuations of real quantities are caused by real shock only; that is, only stochastic technology or government spending shocks play their role. Later research in DSGE models however included Keynesian short-run macroeconomic features (called nominal rigidities), such as Calvo (1983) type staggered pricing behavior and Taylor (1980) type wage contracts. Hence this new DSGE modeling framework labeled as new-neoclassical synthesis or new-Keynesian modeling paradigm. ${ }^{3}$

This new approach combines micro-foundations of both households and firms optimization problems and with a large collection of both nominal and real (price/wage) rigidities that provide plausible short-run dynamic macroeconomic fluctuations with a fully articulated description of the monetary policy transmission mechanism; see, for instance, Christiano et al. (2005) and Smets and Wouters (2003). The key advantage of modern DSGE models, over traditional reduce form macroeconomic models, is that the structural interpretation of their parameters allows to overcome the famous Lucas critique (1976). ${ }^{4}$ Traditional models contained

\footnotetext{
1 Well known DSGE models developed by most of the central banks and international policy institutions as noted by Tovar (2008) are (a) Bank of Canada (TotEM), (b) Bank of England (BEQM), (c) Central bank of Brazil (SAMBA), (d) Central bank of Chile (MAS), (e) Central bank of Peru (MEGA-D), (f) European Central bank (NAWM), (g) Norges Bank (NEMO), (h) Sveriges Riksbank (RAMSES), (i) US Federal Reserve (SIGMA) and (j) IMF (GEM and GIMF). A bird's eye view of various country specific DSGE models is also provided in table C1 of Appendix-C.

${ }^{2}$ For recent contributions that estimate small open economies, see Adolfson et al. (2008), Dib et al. (2008), Justiniano and Preston (2004), Liu (2006) and Lubik and Schorfheide (2005) .

3 In macroeconomic literature, the terms "new-Keynesian" or "new neoclassical synthesis" are being used synonymously; see, Clarida, Gali and Getler (1999), Gali and Getler (2007), Goodfriend (2007), Goodfriend and King (1997), Mankiw (2006) and Romer (1993).

${ }^{4}$ Lucas (1976) and Lucas and Sargent (1979 argue that if private agents behave according to a dynamic optimization approach and use available information rationally, they should respond to economic policy announcements by adjusting their supposedly behavior. Hence reduced form parameter results are subject to Lucas critique. But, DSGE models are based on optimizing agents; deep parameters of these models are therefore less susceptible to this critique.
} 
equations linking variables of interest of explanatory factors such as economic policy variables. One of the uses of these models was therefore to examine how a change in economic policy affected these variables of interest, other things being equal.

In using DSGE models for practical purposes and to recommend how central banks and policy institutions should react to the short-run fluctuations, it is necessary to first examine the possible sources, ${ }^{5}$ as well as to evaluate the degree of nominal and real rigidities present in the economy. In advanced economies, like US and EURO area, it is easy to determine the degree of nominal and real rigidities as these economies are fully documented. In developing economies like Pakistan, where most of economic activities are un-documented (also labeled as informal economy, black economy, or underground economy), it is very difficult to determine the exact degree of nominal and real rigidities present in the economy. However, one can approximate results using own judgments and through well defined survey based methods. ${ }^{6}$

Broadly, this paper carries two dimensional motivation agenda. First, in emerging market economies with complex structures, one of the enduring research questions is to construct and estimate a valid micro-founded economic model featured with nominal rigidities. This issue is really focusable as such economic model which comprehensively explores the transmission mechanism of economic behaviors in the developing economies is scarcely available. Problems in these dimensions are sometimes quite natural for example due to unavailability of high frequency data or because of a major share of the undocumented economy in the observed economic data. This study comes forward to meet this challenge partially (through formal economy channel) by utilizing and constructing ${ }^{7}$ the high frequency available data (quarterly basis) in the DSGE micro-founded model for Pakistan economy.

Second, the best of our knowledge, there is no study available that has evaluated and analyzed Pakistan economy on the lines of micro-founded new-Keynesian models. Among the available literature on economic modeling for Pakistan economy, nonetheless, one may see four major publications with reference to large macroeconometric modeling: (i) Naqvi et al. (1983) and its revised version Naqvi and Ahmed (1986); (ii) Chishti et al. (1992); (iii) Haque et al. (1994) and (iv) Pasha et al. (1995). In addition to this three studies on Computable General Equilibrium (CGE) modeling: (i) McCathy and Taylor (1980); (ii) Siddiqui and Iqbal (2001); and (iii) Siddiqui and Kemal (2006). The studies explore general equilibrium policy and welfare tradeoffs especially on fiscal side of the Pakistan economy. Furthermore, they remain insufficient in answering several policy oriented questions. Among the many other questions these models absolutely fail to take care of Lucas critique. This study therefore also endeavors to fill this gap in the Pakistan economic literature.

This study uses a simplified version of small open economy DSGE model consistent with Kolasa (2008), Liu (2006), Gali and Monacelli (2005) and Lubik and Schorfheide (2005). The overall model specification is restricted with few sources of nominal rigidities, a linear

\footnotetext{
${ }^{5}$ Christanio et al. (2005) and Smets and Wouters (2003) argued that endogenous persistence mechanism, such as habit formation and price indexation, must be added to the basic DSGE model in order to reproduced the observed output and inflation persistence.

${ }^{6}$ See, for instance; Kwapil et al. (2005), Copaciu et al. (2005), and Bosch (2007).

${ }^{7}$ For detail description, see table A1 of appendix A.
} 
production function in labour, and a simple role for the central bank with its two main objectives of price stability and economic growth. Furthermore, foreign sector economy is considered as completely exogenous with its two key variables, output (to capture foreign productivity shock) and real interest rate (foreign monetary policy shock). Using historical data on quarterly basis by applying Bayesian estimation approach vis-à-vis combining with the prior information available in existing literature on Pakistan, this model provide several interesting results ${ }^{8}$, which are discussed in later sections of this paper.

The rest of the paper is organized as follows: section two lay out the structure of the model; section three discusses the estimation methodology; section four carries out empirical results; section five concludes and review literature and model canonical representation are provided in appendix.

\section{STRUCTURE OF THE MODEL}

In this section, we derive a small-scale open-economy DSGE model for Pakistan. Following mainly Kolasa (2008), Liu (2006), Gali and Monacelli (2005) and Lubik and Schorfheide (2005), the models structure begins with the world-economy as inhabited by a continuum of infinitelived households, (indexed by $i \in[0,1]$ ) who take decisions on consumption and savings, and set wages in a staggered fashion. ${ }^{9}$ There is a set of firms that produce differentiated varieties of tradable intermediate goods. They have monopoly power over the varieties they produce and set prices in a staggered way. Another group of firms are importers that distribute domestically different varieties of foreign intermediate goods. These firms have monopoly power over the varieties they distribute, and also set prices in a Calvo-type staggered fashion. Finally, we assume symmetric preferences and technologies and allowing potentially rich exchange rate dynamics under the assumption of complete international asset markets.

\subsection{Domestic Households Preferences}

The domestic economy is inhabited by a representative household who derives its utility from consumption $C_{t}$, and leisure $1-L_{t}$. Its preferences are described by an intertemporal utility function ${ }^{10}$ :

$$
U_{0}=E_{0}\left(\sum_{t=0}^{\infty} \beta_{t}\left[U_{1}\left(C_{t}, H_{t}\right)-U_{2}\left(L_{t}\right)\right]\right)
$$

Where,

\footnotetext{
8 Using Global Sensitivity Analysis (GSA) toolkit, we computed model parameter stability estimates, which are also provided in the appendix-B of this paper.

${ }^{9}$ Each household lives in one of two countries, individual defined on the interval, $i \in[0, n]$ lives in the home-country, and remaining on the interval $i \in[0, n]$ lives in the foreign-country. The value of $n$ measures the relative size of the home-country.

10 We do not include real money balances (M/P) into our utility function. Because DSGE models assume nominal short-term interest rate as the monetary policy instrument, so that money supply is considered as endogenous; see for instance, Woordford (2003). In the case of Pakistan, this critical assumption also holds as a recent empirical study by Omer and Saqib (2008) argue that money supply in Pakistan is endogenous.
} 


$$
U_{1}\left(C_{t}, H_{t}\right)=\frac{1}{1-\sigma}\left(C_{t}-H_{t}\right)^{1-\sigma} \quad \text { and } \quad U_{2}\left(L_{t}\right)=\frac{1}{1+\varphi}\left(L_{t}\right)^{1+\varphi}
$$

Where $\beta_{t} \in(0,1)$ is the intertemporal discount factor which describe rate of time preferences, $\sigma$ is the inverse of the elasticity of intertemporal substitution in consumption and $\varphi$ is the inverse of wage elasticity of labour supply. We introduce external habit formation for the optimization household as $H_{t}=h C_{t-1}$ with degree of intensity ${ }^{11}$ indexed by $h$, where $C_{t-1}$ is the aggregate part of consumption index. As usual, it is assumed that, $\sigma>0$ and $\varphi>1$.

The variable $C_{t}$ is defined as the composite consumption index of foreign and domestically produced goods:

$$
C_{t}=\left[(1-\alpha)^{\frac{1}{\eta}} C_{H, t}^{\frac{\eta-1}{\eta}}+\alpha^{\frac{1}{\eta}} C_{F, t}^{\frac{\eta-1}{\eta}}\right]^{\frac{\eta}{\eta-1}}
$$

Where $\eta>0$ is the elasticity of intratemporal substitution between a bundle of home goods $C_{H, t}$ and a bundle of foreign goods $C_{F, t}$, while $\alpha \in(0,1)$ is the trade share also measures the degree of openness. The aggregate consumption indices $C_{H, t}$ and $C_{F, t}$ are defined respectively as:

$$
C_{H, t} \equiv\left[\int_{0}^{1} C_{H, t}(i)^{\frac{\varepsilon-1}{\varepsilon}} d i\right]^{\frac{\varepsilon}{\varepsilon-1}} \quad \text { and } \quad C_{F, t} \equiv\left[\int_{0}^{1} C_{F, t}(i)^{\frac{\varepsilon-1}{\varepsilon}} d i\right]^{\frac{\varepsilon}{\varepsilon-1}}
$$

Where $C_{H, t}(i)$ and $C_{F, t}(i)$ are respectively the domestic households consumption levels of home $i^{\text {th }}$ good, with $i \in[0, n]$ and foreign $i^{\text {th }} \operatorname{good}$, with $i \in[n, 1]$. It is also assumed that parameter, $\varepsilon>0$ is the elasticity of intratemporal substitution among goods produced to be same in two countries.

Under the supposition of CES, continuous time aggregator from equation (3) further yields respective demand functions for $C_{H, t}$ and $C_{F, t}$. These demand functions obtained after optimal allocation for good $i$ over continuous time scale. The demand functions are:

$$
C_{H, t}(i)=\left[\frac{P_{H, t}(i)}{P_{H, t}}\right]^{-\varepsilon} C_{H, t} \quad \text { and } \quad C_{F, t}(i)=\left[\frac{P_{F, t}(i)}{P_{F, t}}\right]^{-\varepsilon} C_{F, t}
$$

Where $P_{H, T}(i)$ and $P_{F, T}(i)$ are prices of domestic and foreign good $i$ respectively. Under the assumption of symmetry across $i$ household allocate aggregate expenditure based on the following demand functions:

\footnotetext{
${ }^{11}$ It also shows habit persistence parameter to reproduce observed output, rages from $0 \leq h \leq 1$.
} 


$$
C_{H, t}=(1-\alpha)\left(\frac{P_{H, t}}{P_{t}}\right)^{-\eta} C_{t} \quad \text { and } \quad C_{F, t}=\alpha\left(\frac{P_{F, t}}{P_{t}}\right)^{-\eta} C_{t}
$$

Where $P_{H, t}$ and $P_{F, t}$ are domestic and foreign prices indices and $P_{t} \equiv\left[(1-\alpha) P_{H, t}^{1-\eta}+\alpha P_{F, t}^{1-\eta}\right]^{\frac{1}{1-\eta}}$ is the consumer price index (CPI).

The household does want to maximize its utility level subject to the following budget constraints at time $t$ :

$$
\int_{0}^{1}\left(P_{H, t}(i) C_{H, t}(i)+P_{F, T}(i) C_{F, t}(i)\right) d i+E\left(Q_{t, t+1} D_{t+1}\right) \leq D_{t}+W_{t} L_{t}
$$

Where $Q_{t, t+1}$ is defined as a stochastic discount factor for assessing consumption streams ${ }^{12}$ (or asset price kernel) with the property that the price in period $t$ of any bond portfolio with random values $D_{t}$ (denotes nominal payoffs from a portfolio of assets at time $t$ - 1 ) in the following period is given by: $B_{t}=E_{t}\left[Q_{t, t+1} D_{t+1}\right] .{ }_{13} W_{t}$ is the nominal wage for labour services provided to firms. Since total consumption expenditure for the domestic household is given by $P_{H, T} C_{H, t}+P_{F, T} C_{F, t}=P_{t} C_{t}$.

Hence in the aggregate, household faces the budget constraint as:

$$
P_{H, t} C_{H, t}+P_{F, T} C_{F, t}+E\left(Q_{t, t+1} D_{t+1}\right) \leq D_{t}+W_{t} L_{t} \quad \text { or } \quad P_{t} C_{t}+B_{t} \leq D_{t}+W_{t} L_{t}
$$

Consider $\Xi_{t}$ is the marginal utility of income and labour-leisure choice ${ }^{14}$ is followed by the intratemporal optimality condition: $\Xi_{t t}=P_{t} / W_{t}$, Therefore, intertemporal consumption choice is obtained after maximizing the life time utility function subject to budget constraint (7). So optimization problem yields the following FOCs are:

$$
\left(C_{t}-h C_{t-1}\right)^{-\sigma} \frac{W_{t}}{P_{t}}=L_{t}^{\varphi}
$$

By equating marginal rates of substitution to relative prices, yields the optimal portfolio choice as:

$$
\frac{U_{1}^{c}\left(C_{t}, H_{t}\right)}{U_{1}^{c}\left(C_{t+1}, H_{t+1}\right)}=\frac{\beta}{Q_{t, t+1}}\left(\frac{P_{t}}{P_{t+1}}\right)
$$

\footnotetext{
${ }^{12}$ In terms of this discount factor, the riskless short term nominal interest rate $R_{t}$ corresponds to the solution to the equation: $1 / R_{t}=E_{t}\left(Q_{t, t+1}\right)$

$13 Q_{t, t+1}$ remains a stochastic variable at time $t$, and $E_{t}$ denotes expectations conditional upon the state of the world at time $t$.

${ }^{14}$ To drive, FOCS from objective function subject to budget constraint, it is assumed that inverse of wage elasticity of labour supply is zero.
} 


$$
\begin{array}{ll}
\Rightarrow & Q_{t, t+1}=\beta E_{t}\left\{\left(\frac{P_{t}}{P_{t+1}}\right)\left(\frac{U_{1}^{c}\left(C_{t+1}, H_{t+1}\right)}{U_{1}^{c}\left(C_{t}, H_{t}\right)}\right)\right\} \\
\Rightarrow & Q_{t, t+1}=\beta E_{t}\left\{\left(\frac{P_{t}}{P_{t+1}}\right)\left(\frac{C_{t+1}-h C_{t}}{C_{t}-h C_{t-1}}\right)^{-\sigma}\right\}
\end{array}
$$

The equation (9) can also be translated into $\Delta_{t}$ form as:

$$
Q_{t, t+1}=\beta E_{t}\left\{\left(\frac{P_{t}}{P_{t+1}}\right)\left(\frac{\Xi_{t t+1}}{\Xi_{t t}}\right)\right\}
$$

Since monetary authority's main instrument is assumed to be short term nominal interest rates as: $R_{t}=E_{t}\left(\frac{1}{Q_{t, t+1}}\right)$, so equation (10) can also be represented as:

$$
\beta R_{t} E_{t}\left\{\left(\frac{P_{t}}{P_{t+1}}\right)\left(\frac{\Xi_{t t+1}}{\Xi_{t t}}\right)\right\}=1
$$

Further, equations (5), (8) and (9) can also be expressed in simple log-linearization form as:

$$
\begin{aligned}
& c_{H, t}=-(1-\alpha) {\left[\eta\left(p_{H, t}-p_{t}\right)+c_{t}\right] \quad \text { and } \quad c_{F, t}=-\alpha\left[\eta\left(p_{F, t}-p_{t}\right)+c_{t}\right] } \\
& w_{t}-p_{t}=\varphi l_{t}+\frac{\sigma}{1-h} c_{t} \\
& E_{t} c_{t+1}-\left(\frac{1-h}{\sigma}\right)\left(r_{t}-E_{t} \pi_{t+1}\right)=c_{t}
\end{aligned}
$$

Where, is $\pi_{t+1}=p_{t+1}-p_{t}$ is CPI inflation and $c_{t}=\frac{1}{1-h}\left(c_{t}-h c_{t-1}\right)$ is simple log-form of consumption variable.

\subsection{Domestic Producers and Firms}

The domestic economy is also inhabited by domestic producers, own identical monopolistically competitive firms, producing differentiated goods. There is also a continuum of firms, indexed by $j \in(0,1)$ where each firm maximizes its profits, subject to an isolated demand curve (5) and use only a homogenous type of labour for production. 
Consider domestic firms operate the same CRS-technology (i.e., firms have access to a linear production technology) that uses labour as its only input:

$$
Y_{H, t}=A_{t} L_{t}(j)
$$

Where, $A_{t}$ is the country specific labor productivity shock. We define aggregate output as:

$$
Y_{t}=\left[\int_{0}^{1} Y_{t}(j)^{-(1-\rho)} d j\right]^{\frac{1}{-(1-\rho)}}
$$

The log-linear aggregate production function can be written as:

$$
\ln Y_{t}=\left[\int_{0}^{1} \ln Y_{t}(j)^{-(1-\rho)} d j\right]^{\frac{1}{-(1-\rho)}}=\ln \left(A_{t}\right)+\ln \left(L_{t}\right)
$$

Let, $\ln \left(A_{t}\right)=a_{t}$, then (14) can be represented as:

$$
y_{t}=a_{t}+l_{t}
$$

If $T C_{t}$ represents the real total cost, then:

$$
T C_{t}=\frac{W_{t}}{P_{H, t}} \frac{Y_{t}}{A_{t}}
$$

By differentiating w.r.t. $Y_{t}(19)$ gives real marginal cost as:

$$
M C_{t}=\frac{W_{t}}{P_{H, t}} \frac{1}{A_{t}} \quad \text { or } \quad \tilde{m c_{t}}=\tilde{w}_{t}-\tilde{p}_{H, t}-a_{t}
$$

This implies that real marginal cost is positively related with real wages and negatively with labor factor productivity.

\subsubsection{Calvo-Type Price Setting Behavior}

For our model, Calvo (1983) type staggered-price setting is assumed. This means that domestic differentiating goods are defined subject to Calvo-type price-setting. Consider, at each period, only $1-\theta_{t}$ fraction of randomly selected domestic firms set prices optimally, while 
$\theta_{t} \in[0,1]$ firms keep their prices unchanged ${ }^{15}$. As a result the average duration of a price is given by $\frac{1}{1-\theta_{t}}$. This implies that $\theta_{t}$ firms are assumed to reset their prices, $P_{t}^{I}(j)$ by indexing it to last period inflation. Therefore, $\theta_{t}$ becomes a natural index of price stickiness. The index of domestic prices ${ }^{16}$ is defined as:

$$
P_{H, t}^{I}=P_{H, t}(j)\left(\frac{P_{H, t-1}}{P_{H, t-2}}\right)^{\theta_{H}}
$$

Where $P_{H, t}(j)=P_{H, t}(k)$ for all continuum of firms $j, k$. Let each home firm $j$ sets a new price $P_{H, t}^{*}(j)$ in order to maximize the present market value of its stream of expected future profits. Therefore domestic price level can be defined as:

$$
P_{H, t}=\left[\theta_{H}\left\{P_{H, t-1}\left(\frac{P_{H, t-1}}{P_{H, t-1}}\right)^{\theta_{H}}\right\}^{1-\rho}+\left(1-\theta_{H}\right)\left(P_{H, t}^{*}\right)^{1-\rho}\right]^{\frac{1}{1-\rho}}
$$

In aggregate, firms re-optimize their prices and maximize their profits after setting the new price $P_{H, t}^{*}(j)$ at time $t$ as:

$$
\max \sum_{k=0}^{\infty} E_{t}\left[\left(\theta_{H}\right)^{k}\left\{Q_{t, t+k}\left(Y_{H, t+k}\left[P_{H, t}^{*}-N M C_{H, t+k}\right]\right)\right\}\right]
$$

With respect to $P_{H, t}^{*}(j)$, Subject to the following demand function:

$$
Y_{H, t+k} \leq\left(C_{H, t+k}+C_{H, t+k}^{*}\right)\left[\frac{P_{H, t}^{*}}{P_{H, t+k}}\right]^{-\epsilon}
$$

Where $N M C_{H, t+k}$ is the nominal marginal cost and demand of firm's product drives both from domestic consumption, $C_{H, t}$ as well as foreign consumption, $C_{F, t}$. The first order condition with (23) takes the form:

\footnotetext{
${ }^{15} \theta_{t}$ firms adjust prices according to steady state inflation rate $\pi_{t}$. This notion introduces inflation persistence by allowing for price indexation to previous inflation.

${ }^{16}$ The degree of price stickiness is assumed to be same as the fraction of past inflation indexation. The reason of this crude assumption is that it validates a basic rationale of Phillips curve. "In the long-run Phillips Curve is vertical", see for instance, Gali and Gertler (1999).
} 


$$
\sum_{k=0}^{\infty} E_{t}\left[\left(\theta_{H}\right)^{k}\left\{Q_{t, t+k}\left(Y_{H, t+k}\left[P_{H, t}^{*}-\frac{\epsilon}{\in-1} N M C_{H, t+k}\right]\right)\right\}\right]=0
$$

Where $\frac{\epsilon}{\epsilon-1}$ is considered as desired or frictionless markup. ${ }^{17}$ The above condition (24) is linearized around zero-inflation steady-state. So optimal condition (24) can be rewrite after dividing by $P_{H, t-1}$ as:

$$
\sum_{k=0}^{\infty} E_{t}\left[\left(\theta_{H}\right)^{k}\left\{Q_{t, t+k}\left(Y_{H, t+k}\left[\frac{P_{H, t}^{*}}{P_{H, t-1}}-\frac{\in}{\in-1} \frac{P_{H, t+k}}{P_{H, t-1}} \frac{N M C_{H, t+k}}{P_{H, t+k}}\right]\right)\right\}\right]=0
$$

Letting, $\pi_{H, t+k}=\frac{P_{H, t+k}}{P_{H, t-1}}$ and $M C_{H, t+k}=\frac{N M C_{H, t+k}}{P_{H, t+k}}$ which is a real marginal cost in period $t+k$. Hence, equation (25) can be written as:

$$
\sum_{k=0}^{\infty} E_{t}\left[\left(\theta_{H}\right)^{k}\left\{Q_{t, t+k}\left(Y_{H, t+k}\left[\frac{P_{H, t}^{*}}{P_{H, t-1}}-\frac{\epsilon}{\in-1} \pi_{H, t+k} M C_{H, t+k}\right]\right)\right\}\right]=0
$$

From (8) we can incorporate the value of $Q_{t, t+k}=\beta^{k} E_{t}\left\{\left(\frac{P_{t}}{P_{t+k}}\right)\left(\frac{C_{t+k}}{C_{t}}\right)^{-\sigma}\right\}$ in equation (26) as:

$$
\sum_{k=0}^{\infty}\left(\beta \theta_{H}\right)^{k} \frac{P_{t}}{C_{t}^{-\tau}}\left[E_{t}\left\{\left(\frac{C_{t+k}^{-\sigma}}{P_{t+k}} Y_{H, t+k}\left[\frac{P_{H, t}^{*}}{P_{H, t-1}}-\frac{\epsilon}{\in-1} \pi_{H, t+k} M C_{H, t+k}\right]\right)\right\}=0\right.
$$

Since $\frac{P_{t}}{C_{t}^{-\sigma}}$ is independent of summation and its values are known at time $t$, so (27) yields:

$$
\sum_{k=0}^{\infty}\left(\beta \theta_{H}\right)^{k}\left[E_{t}\left\{\left(\frac{C_{t+k}^{-\sigma}}{P_{t+k}} Y_{H, t+k}\left[\frac{P_{H, t}^{*}}{P_{H, t-1}}-\frac{\epsilon}{\in-1} \pi_{H, t+k} M C_{H, t+k}\right]\right)\right\}\right]=0
$$

In the zero inflation steady-state, $\frac{P_{H, t}^{*}}{P_{H, t-1}}=1$ and $\pi_{H, t+1}=1$. So log-linear form of (28) at zero inflation steady-state is:

\footnotetext{
17 In the limiting case with no price rigidities (say, $\theta=0$ ), the previous condition collapses to the familiar optimal price-setting condition under flexible prices. See., Gali (2008).
} 


$$
p_{H, t}^{*}-p_{H, t-1}=\sum_{k=0}^{\infty}\left(\beta \theta_{H}\right)^{k}\left[\left(1-\beta \theta_{H}\right) E_{t}\left\{m c_{t+k}\right\}+E_{t}\left\{\pi_{H, t+k}\right\}\right]
$$

Where $m c_{t+k}$ denotes log deviation of marginal cost from its steady state value. The first order Taylor expansion of (29) yields:

$$
\begin{aligned}
& p_{H, t}^{*}-p_{H, t-1}=\pi_{H, t}+\left(1-\beta \theta_{H}\right) m c_{t}+ \\
& \left(\beta \theta_{H}\right) \sum_{k=0}^{\infty}\left(\beta \theta_{H}\right)^{k}\left[\left(1-\beta \theta_{H}\right) E_{t}\left\{m c_{t+k+1}\right\}+E_{t}\left\{\pi_{H, t+k+1}\right\}\right] \\
\Rightarrow \quad & p_{H, t}^{*}-p_{H, t-1}=\pi_{H, t}+\left(1-\beta \theta_{H}\right) m c_{t}+\left(\beta \theta_{H}\right) E_{t}\left\{\pi_{H, t+1}\right\}
\end{aligned}
$$

Combining the log-linear of equation (30) with the result (22) yields the New Keynesian Phillips Curve (NKPC):

$$
\pi_{H, t}=\beta\left(1-\theta_{H}\right) E_{t}\left\{\pi_{H, t+1}\right\}+\theta_{H} \pi_{H, t-1}+\lambda_{H} m c_{t}
$$

Where, $\lambda_{H}=\frac{\left(1-\theta_{H}\right)\left(1-\beta \theta_{H}\right)}{\theta_{H}}$. The NKPC equation (31) implies that home country's inflation dynamics drives from both forward looking and backward looking components. The above NKPC representation also called a hybrid version of NKPC with forward looking and backward looking behavior. It further shows that real marginal cost is also a main determinant of domestic inflation.

\subsection{Import Goods Retailers}

Following Gali and Monacelli (2005) and Monacelli (2005), we assume that the law-of-one price (LOP) holds at the wholesale level for imports. But, endogenous fluctuations from purchasing power parity (PPP) in the short run arise due to the existence of monopolistically competitive importers. Since, they keep domestic import prices over and above the marginal cost. As a result, the LOP fails to hold at the retail level for domestic imports. Importers purchase foreign goods at world-market prices $P_{F, t}^{*}(j)$ so that the law of one price holds at the border. These purchased foreign goods are then sell to domestic consumers and a mark-up is charged over their cost, which creates a wedge between domestic and import prices of foreign goods when measured in the same currency.

Therefore, law of one price (l.o.p.) gap can be defined as: ${ }^{18}$

18 If PPP holds, then 1.o.p gap is translated into $\psi_{F, t}=1$. This implies that pass-through from exchange rate movements to the domestic currency prices of imports is imperfect as importers adjust their pricing behavior to extract optimal revenue from consumers. See, Monacelli (2005). 


$$
\psi_{F, t}=\frac{P_{t}^{*}}{e_{t} P_{F, t}}
$$

Where $e_{t}$ is the nominal exchange rate. Following a similar staggered-pricing argument (29) as defined in the case of domestic producer, the optimal price setting behavior for the domestic monopolistically competitive importer could be defined as:

$$
p_{F, t}^{*}-p_{F, t-1}=\sum_{k=0}^{\infty}\left(\beta \theta_{F}\right)^{k}\left[\left(1-\beta \theta_{F}\right) E_{t}\left\{m c_{t+k}\right\}+E_{t}\left\{\pi_{F, t+k}\right\}\right]
$$

Where, $\theta_{F} \in[0,1]$ is the stickiness parameter of importer retailers that cannot re-optimize their prices every period. However, in order to maximize profits, domestic retailers set domestic currency price of imported goods as a markup over $\psi_{F, t}$, as they are concerned with the law of one gap and future path of imported inflation. Therefore, endogenous fluctuations from PPP occurred which provides a mechanism for incomplete pass-through in the short-run. This mechanism finally results in a new Keynesian Phillips curve relationship. Hence, equation (31) can be defined in term of $\pi_{F, t}$ as:

$$
\pi_{F, t}=\beta\left(1-\theta_{F}\right) E_{t}\left\{\pi_{F, t+1}\right\}+\theta_{F} \pi_{F, t-1}+\lambda_{F} \psi_{F, t}
$$

Where $\quad \lambda_{F}=\frac{\left(1-\theta_{F}\right)\left(1-\beta \theta_{F}\right)}{\theta_{F}}$. Since consumer price index $(\mathrm{CPI})$ is defined as: $P_{t} \equiv\left[(1-\alpha) P_{H, t}^{1-\eta}+\alpha P_{F, t}^{1-\eta}\right]^{\frac{1}{1-\eta}}$, therefore using (31) and (34) the log-linear form of overall inflation is defined as:

$$
\pi_{t} \equiv\left[(1-\alpha) \pi_{H, t}+\alpha \pi_{F, t}\right]
$$

The above functional form of overall inflation with specifications (31) and (34) completes inflation dynamics for a small open economy like Pakistan.

\subsection{Foreign Sector Economy}

In this section we drive the open economy dynamics between inflation; terms of trade; real exchange rate; international risk sharing and un-covered interest parity. Since $e_{t}$ is nominal exchange rate. We defined home country real exchange rate as:

$$
R E R_{t} \equiv \frac{e_{t} P_{t}}{P_{t}^{*}}
$$


Similarly, counterpart of home country, foreign country real exchange rate is the inverse of (36). Due to law of one price gap, term of trade between home and foreign countries may differ. Therefore, domestic term of trade (TOT) $S_{t}$ and foreign TOT $S_{t}^{*}$ can be defined as:

$$
S_{t} \equiv \frac{P_{F, t}}{P_{H, t}} \quad \text { and } \quad S_{t}^{*} \equiv \frac{P_{H, t}^{*}}{P_{F, t}^{*}}
$$

The domestic TOT is thus the price of foreign goods (imports) per unit of domestic goods (exports) and foreign TOT is domestic goods per unit the price of foreign goods. Both Terms of trade coincide inversely only if pass-through is perfect. But in case of imperfect pass-through, the relationship between law of one price gaps and terms of trade can be defined as:

$$
\frac{\psi_{F, t}}{s_{t}} \equiv \frac{\psi_{H, t}^{*}}{s_{t}^{*}}
$$

As log-linearising of CPI formula around the steady-state yields the following relationship: $p_{t} \equiv\left[(1-\alpha) p_{H, t}+\alpha p_{F, t}\right]$ and log-linear form of TOT $s_{t}$ as: $s_{t} \equiv p_{F, t}-p_{H, t}$. Solving both simultaneously as:

$$
\begin{aligned}
p_{t} & \equiv\left[(1-\alpha) p_{H, t}+\alpha\left(p_{H, t}+s_{t}\right)\right] \\
\Rightarrow \quad p_{t} & \equiv\left[p_{H, t}+\alpha s_{t}\right]
\end{aligned}
$$

Equation (39) in first difference form can be represented in inflation notation as:

$$
\tilde{\pi}_{t} \equiv\left[\tilde{\pi}_{H, t}+\alpha \Delta s_{t}\right]
$$

Solving (35) and (40) we have;

$$
\begin{aligned}
& \tilde{\pi}_{H, t}+\alpha \Delta s_{t}=(1-\alpha) \tilde{\pi}_{H, t}+\alpha \tilde{\pi}_{F, t} \\
\Rightarrow \quad & s_{t}=s_{t-1}+\tilde{\pi}_{F, t}-\tilde{\pi}_{H, t}
\end{aligned}
$$

This shows that domestic TOT is positively related with foreign inflation and its own lag and negatively with domestic inflation.

The real exchange rate of (36) in log-linear form $\boldsymbol{q}_{\mathrm{t}}$ can be presented after solving (32), (36) and (37) as:

$$
q_{t}=-\tilde{\psi}_{t}-(1-\alpha) s_{t}
$$


Where $\psi_{t} \equiv \ln \left(\Psi_{t}\right)=p_{t}^{*}-p_{F, t}-e_{t}$ is LOP gap. If this is equal to one then import price index is equal to foreign price index divided by nominal exchange rate.

The equation (42) shows that real exchange rate negatively related with both law of one price gap as well as terms of trade.

The log-linear transformation of (36) yields nominal exchange rate relationship as:

$$
\Delta \tilde{e}_{t}=\tilde{\pi}_{t}^{*}+\Delta q_{t}-\tilde{\pi}_{t}
$$

Since, under the assumption of complete international financial markets implies perfect risksharing between households in both countries. This means that the expected nominal return from risk-free bounds in home currency terms must be same as the expected domestic currency returns from foreign bonds. So,

$$
E_{t} Q_{t, t+1}=\left(E_{t} Q_{t, t+1}^{*} \frac{e_{t+1}}{e_{t}}\right)
$$

Using this notion (44), we can extent (9) as:

$$
\begin{aligned}
& \beta E_{t}\left\{\left(\frac{P_{t}}{P_{t+1}}\right)\left(\frac{U_{1}^{c}\left(C_{t+1}, H_{t+1}\right)}{U_{1}^{c}\left(C_{t}, H_{t}\right)}\right)\right\}=Q_{t, t+1}=\beta E_{t}\left\{\left(\frac{P_{t}^{*}}{P_{t+1}^{*}}\right)\left(\frac{U_{1}^{c}\left(C_{t+1}^{*}, H_{t+1}^{*}\right)}{U_{1}^{c}\left(C_{t}^{*}, H_{t}^{*}\right)}\right)\left(\frac{e_{t}}{e_{t+1}}\right)\right\} \\
& \beta E_{t}\left\{\left(\frac{P_{t}}{P_{t+1}}\right)\left(\frac{\Xi_{t+1}}{\Xi_{t}}\right)\right\}=Q_{t, t+1}=\beta E_{t}\left\{\left(\frac{P_{t}^{*}}{P_{t+1}^{*}}\right)\left(\frac{\Xi_{t+1}^{*}}{\Xi_{t}^{*}}\right)\left(\frac{e_{t}}{e_{t+1}}\right)\right\}
\end{aligned}
$$

The log-linear form of (46) gives a relationship between marginal utilities across countries adjust for purchasing power as:

$$
\Xi_{t}=\Xi_{t}^{*}-q_{t}
$$

The assumption of complete international asset market also holds another relationship called un-covered interest parity condition (UIP).

$$
E_{t}\left\{Q_{t, t+1}\left(R_{t}-R_{t}^{*} \frac{e_{t}}{e_{t+1}}\right)\right\}=0
$$

The log-linear representation of (48) around steady-state yields the following relationship:

$$
r_{t}-r_{t}^{*}=E_{t} \Delta \tilde{e}_{t+1}
$$


This equation implies that the interest rate differential is related with expected future exchange rate depreciation, which defined as un-covered interest parity. Similarly, expression (49) can also be written as:

$$
-\left(r_{t}-\pi_{t+1}\right)-\left(r_{t}^{*}-\pi_{t+1}^{*}\right)=E_{t} \Delta q_{t+1}
$$

This equation implies that expected changes in real exchange rate determine by current real interest rate differentials with negative sings.

\subsection{Monetary Policy Reaction function}

It is assumed that domestic vis-à-vis foreign central banks follow Taylor-type reaction functions. Since the basic objective of the central bank is to stabilize both output and inflation. So to specify this reaction function it needs to adjusts nominal interest rate in response to deviations of inflation, a measure of output and exchange rate depreciation from their targets. Following Clarida, Gali and Gertler (2001), simple reaction function can be defined as:

$$
r_{t}=\rho_{r} r_{t-1}+\left(1-\rho_{r}\right)\left(\phi_{1} \tilde{\pi}_{t}+\phi_{2} \Delta \tilde{y}_{t}\right)+v_{t}^{r}
$$

Where $\rho_{r}$ is the degree of interest rate smoothing and $\phi_{1}, \phi_{2}$ are relative weights on inflation and output growth respectively. It should be note that this model is estimated using a speed limit policy rather than the traditional Taylor-rule based output and inflation. A recent study Malik and Ahmed (2007) argues that State bank of Pakistan do not follow a simple Taylor-typerule, as SBP also considers various other macroeconomic factors, like exchange rate smoothing, etc., while conducting its monetary policy. Following this approach, we initially included these factors into (51), but due to identification issues we again restricted with the simple version, as describes above.

\subsection{General Equilibrium}

Using the above model setup, we can drive general equilibrium dynamics around their steadystate level. The general equilibrium is achieved from goods market equilibrium and labour market equilibrium. The goods market equilibrium derived from aggregate demand side forces and labour market equilibrium dynamics emerge from aggregate supply side forces. So, the general equilibrium of the whole model is achieved from these market equilibriums.

\subsubsection{Aggregate Demand Side: Goods market Equilibrium and IS-Curve}

To find goods market equilibrium, output is equating with domestic consumption, government investment and foreign consumption of domestic produced goods. Hence, market clearing condition is;

$$
Y_{H, t}=C_{H, t}+C_{H, t}^{*}
$$


Since, $C_{H, t}=(1-\alpha)\left(\frac{P_{H, t}}{P_{t}}\right)^{-\eta} C_{t}$ and $C_{H, t}^{*}=(1-\alpha)\left(\frac{e_{t} P_{H, t}}{P_{t}^{*}}\right)^{-\eta} C_{t}^{*}$, the log-linear form of this setup is given as:

$$
\left\{\begin{array}{lll}
\tilde{y}_{H, t}=(1-\alpha) \tilde{c}_{H, t}+\alpha \tilde{c}_{H, t}^{*} & \\
\tilde{c}_{H, t}=-\eta\left(\tilde{p}_{H, t}-\tilde{p}_{t}\right)+\tilde{c}_{t} & \text { or } & \tilde{c}_{H, t}=\alpha \eta\left(s_{t}\right)+\tilde{c}_{t} \\
\tilde{c}_{H, t}^{*}=-\eta\left(\tilde{e}_{t}+\tilde{p}_{H, t}-\tilde{p}_{t}^{*}\right)+\tilde{c}_{t}^{*} & \text { or } \quad \tilde{c}_{H, t}^{*}=\eta\left(s_{t}+\psi_{t}\right)+\tilde{c}_{t}^{*}
\end{array}\right.
$$

Final representation after solving (53) simultaneously as:

$$
\tilde{y}_{H, t}=\alpha \eta \psi_{t}+(1-\alpha)\left\{c_{t}+\alpha \eta s_{t}\right\}+\alpha\left\{\eta\left(s_{t}+\psi_{t}\right)+c_{t}^{*}\right\}
$$

or

$$
y_{t}=(2-\alpha) \alpha \eta s_{t}+(1-\alpha) c_{t}+\alpha \eta \psi_{t}+\alpha y_{t}^{*}
$$

It should also be note that if we plug value of $\alpha$ is equal to zero then this model converges to closed economy.

\subsubsection{Aggregate Supply Side: Marginal Cost and inflation Dynamics}

Since we already derived domestic firm's price setting behavior in terms of NKPC in (29) as:

$$
\pi_{H, t}=\beta\left(1-\theta_{H}\right) E_{t}\left\{\pi_{H, t+1}\right\}+\theta_{H} \pi_{H, t-1}+\lambda_{H} m c_{t}
$$

Where $\lambda_{H}=\frac{\left(1-\theta_{H}\right)\left(1-\beta \theta_{H}\right)}{\theta_{H}}$ and real marginal cost is $m c_{t}=w_{t}-p_{H, t}-a_{t}$.

Assuming symmetrical equilibrium, real marginal cost can also be rewrite as:

$$
m c_{t}=\left(\tilde{w}_{t}-p_{t}\right)+\left(p_{t}-p_{H, t}\right)-a_{t}
$$

Using (13) and (39) the above expression can also be written as:

$$
m c_{t}=\varphi n_{t}+\alpha s_{t}+\frac{\sigma}{1-h}\left(c_{t}-h c_{t-1}\right)-a_{t}
$$

Since, simple log-linear representation of cob-Douglas production function with one input (labour) is:

$$
y_{t}=n_{t}+a_{t}
$$


Hence, the final representation of (57) is given as:

$$
m c_{t}=\varphi y_{t}+\alpha s_{t}+\frac{\sigma}{1-h}\left(c_{t}-h c_{t-1}\right)-(1+\varphi) a_{t}
$$

This model is finally solved using the general methodology provided in Klein (2000). This methodology also considered the autoregressive shocks as exogenous processes. The detail list of endogenous variables and exogenous processes are described in appendix table B1 of appendix-B.

\section{THE EMPIRICAL ANALYSIS}

This section briefly outlines the empirical setup by illustrating data, choice of priors and estimation methodology used in this paper.

\subsection{Data}

To estimate the model parameters, data over the quarterly frequencies from 1984:Q1 to 2007:Q4 (post floating period) is used on eight macroeconomic variables: domestic output $\left(\mathrm{y}_{\mathrm{t}}\right)$; foreign output $\left(\mathrm{y}^{*}{ }_{\mathrm{t}}\right)$; domestic overall inflation $\left(\pi_{\mathrm{t}}\right)$; imported inflation $\left(\pi_{\mathrm{F}, \mathrm{t}}\right)$;domestic interest rate $\left(\mathrm{r}_{\mathrm{t}}\right)$; foreign real interest rate $\left(\mathrm{r}_{\mathrm{t}}^{*}\right)$; real exchange rate $\left(\mathrm{q}_{\mathrm{t}}\right)$; and term of trade $\left(\mathrm{s}_{\mathrm{t}}\right)$. Since the model has implications for the log-deviations from the steady-state of all these variables, so we pre-process the data before the estimation stage. Details on the construction and the sources of the data set are provided in appendix-A. Pair wise correlation matrix of above mentioned variables is also available in table A2 of appendix-A. These correlations are consistent with the standard theory.

\subsection{Choice of Priors}

According to the Schorfiede (2000), priors can be gleaned from personal introspection to reflect strongly held beliefs about the validity of economic theories. Priors also reflect researcher confidence about the likely location of structural parameter of the model. In practice, priors are chosen based on observation, facts and from existing empirical literature.

For our study, two parameters $\alpha$ and $\beta$ fixed ${ }^{19}$ at 0.35 and 0.95 . For parameter $\alpha$ (degree of openness) which is consistent with the average trade to GDP ratio during the sample period. This parameter value can also be depict from figure A3 of appendix-A. The parameter value of discount factor $(\beta)$ is set in order to obtain historical mean of the nominal interest rate in the steady state. The degree of habit persistence (h) in consumption is set as 0.5 with standard deviation equal to 0.2. As usual in the literature, the inverse elasticity of intermporal substitution in consumption $(\sigma)$ assumed to follow normal distribution with prior means 1.0 and standard deviations equal to 0.4. The elasticity of intratemporal substitution between a bundle of home goods $(\eta)$ and the inverse of wage elasticity of labour supply $(\varphi)$ are assumed

\footnotetext{
${ }^{19}$ These fixed parameters are also known as stick priors in Bayesian sense.
} 
to follow gamma distributions with prior means 1.0 and standard deviations equal to 0.4 . See for instance, Smets and Wouters (2003).

Following Ireland (2004) and Lubik and Schorfiede (2005) the parameters measuring the degree of Clavo price stickiness $\left(\theta_{H}\right)$ and $\left(\theta_{F}\right)$ are assumed to have the same mean value equal to 0.50 with standard deviation equal to $0.25 . .^{20}$ In the case of Pakistan, the average frequency of price change of various commodities and average prices (CPI) fall within the interval from 0.45 to 0.55 as shown in the figures A1 and A2 of appendix-A. So the prior value of $\left(\theta_{H}\right)$ is also consistent with the Pakistan's data. The priors on the coefficients in the monetary policy reaction functions are standard: a relatively high prior mean on the inflation coefficient $\left(\phi_{1}\right)$ with mean 1.5 and standard deviation equal to 0.25 and slightly low output growth coefficient $\left(\phi_{2}\right)$ with mean 025 and standard deviation equal to 0.10 . The persistence coefficient domestic and foreign monetary policy reaction function is set to 0.5 with standard deviation equal to 0.20 . Finally all other priors mean values with their standard deviations are available in first column of table B3 in Appendix-B.

\subsection{Bayesian Estimation Approach}

In empirical literature, there are numerous strategies used to determine the parameters of newKeynesian DSGE models. These ranging from pure calibration, e.g., Kydland and Prescott (1982), Monacelli (2005); over generalized method of moments (GMM) for estimation of general equilibrium relationships, e.g., Christiano and Eichenbaum (1992); to full-information based maximum likelihood estimation as in Altug(1989), Mcgrattan (1994), Leeper and Sims (1994), Kim (2000) and Irland (2000). Other studies also proposed mixed strategies like limitedinformation based methods to explore a key question whether a DSGE model matches the data with some certain dimensions. For example, Canova (2002) and Christiano et al. (2005) used minimum distance based criterion to estimate VAR and DSGE model impulse response functions. Further methodological debate can be referred using the following studies by Diebold (1998), Ruge-Murcia (2003) and Tovar (2008).

Other than these proposed estimation and calibration strategies, this study uses another estimation approach called Bayesian estimation approach. This alternative approach is a combination of calibration and estimation of selected model parameters. The fundamental advantage of this approach is a batter adaption of the model to the conditions in the given economy, see e.g., Smets and Wouters (2003).

In any empirical modeling exercise, there are three possible sources of uncertainty; the model itself; the parameterization condition of the model and the data. The debate on the issue of uncertainty is the most important as it provide a difference between frequentist (classical) and Bayesian approach. In classical approach the probability of the occurrence of an event, i.e., the measurement of uncertainty is associated with its frequency. However, in Bayesian approach, the probability of an event is determined by two components; the subjective believe (prior) and

\footnotetext{
${ }^{20}$ For US economy price stickiness parameter value is also taken as 0.5 , see for instance Lubik and Schorfiede (2005).
} 
the frequency of that event. For further detail on this notion, see for instance Gelman (2006) and Koopman et al (2007).

The seminal work on DSGE modeling used this approach started with the study by LandonLane (1998), DeJong et al. (2000), Schorfheide (2000) and Otrok (2001). This approach has been generalized by Lubik and Schorfheide (2005) who estimate a DSGE model without providing restrictions to the determinacy region of the parameter space. Almost all recent studies on DSGE model has been used this approach, e.g., Smets and Wouters (2003), Laforte (2004), Onatski and Williams (2004), Ratto et al. (2008), Adolfson, et al. (2008) and Kolasa (2008).

In practical sense, we try to fit out referenced model, which consists in placing a prior distribution $p(\Gamma)$ on structural parameters $\Gamma$, the estimate of which are then updated using the data $Y^{\mathrm{T}}$ according to the Bayes rule:

$$
p\left(\Gamma / Y^{T}\right)=\frac{p\left(Y^{T} / \Gamma\right)}{p\left(Y^{T}\right)} \propto L\left(\Gamma / Y^{T}\right) p(\Gamma)
$$

Where $p\left(Y^{T} / \Gamma\right)=L\left(\Gamma / Y^{T}\right)$ is the likelihood function $p\left(\Gamma / Y^{T}\right)$ is the posterior distribution of parameters and $p\left(Y^{T}\right)$ is the marginal likelihood defined as:

$$
p\left(Y^{T}\right)=\int p\left(Y^{T} / \Gamma\right) p(\Gamma) d \Gamma
$$

Any DSGE model forms a linear system with rational expectations, the solution to which is of the form:

$$
\begin{aligned}
& R_{t}=B_{1}(\Gamma) R_{t-1}+B_{2}(\Gamma) \mu_{t} \\
& \mu_{t}=B_{3}(\Gamma) \mu_{t-1}+B_{4}(\Gamma) \varepsilon_{t}
\end{aligned}
$$

Where $R_{\mathrm{t}}$ is a vector of endogenous variables, $\mu_{t}$ is a vector of stochastic disturbances and $\varepsilon_{t}$ is a vector of innovations to stochastic shocks and coefficient matrices $A_{i}$ depending on the parameters of the model. The measurement equations (62) and (63) linking observable variables used in the estimation with endogenous variables can be written as:

$$
Y^{T}=C R_{t}
$$

Where, $C$ is the deterministic matrix. The equations (62), (63) and (64) form the state-space representation of the model. The likelihood of which can be evaluated using Kalman filter. The analytical solution of the whole system may not be obtain in general, however the sequence of posterior draws can be obtain using Markov-Chain-Monte-Carlo (MCMC) simulation methodology. This methodology is briefly discussed in Lubik and Schorfheide(2005), Gelman et al. (2006) and Koopman et al. (2007). For our open economy DSGE model the random walk 
Metropolis-Hastings algorithm is used to generate Morkov-Chains (MC) for the model parameters.

\subsection{Fitness and Stability of Model Structural Parameter}

Following Global Sensitivity Analysis (GSA) toolkit, ${ }^{21}$ we assess the fitness and stability of model structural parameters and structural shocks. This toolkit consists of MATLAB program routines, which used Smirnov-test for stability analysis. Ratto (2008) provided detail discussion on using this toolkit with various applied examples.

\section{ESTIMATION RESULTS}

In this section the estimation results from the small open economy DSGE model are discussed. First we shell analyze the parameter estimates and then we shell discuss model impulse response functions with all their possible dynamics.

\subsection{Parameter Estimates}

In line with Bayesian estimation approach by combining the suitable priors with the likelihood leads to an analytically-intractable posterior density. In order to sample from the posterior, random walk Metropolis-Hastings algorithm is used to generate 150,000 draws from the posteriors. We reported the posterior results (parameter estimates) in the second column of table B3 of appendix-B. Furthermore, figure B1 of appendix-B displays kernel estimates of the priors and the posteriors of each parameter. These results show that prior and posterior means are in most the cases considerably away from each other.

The parameter (h) is equal to 0.36 which is a bit lower than its prior mean of 0.5 . This parameter value implies that degree of habit persistence in consumption is quite low as compared with advance economies; see for instance, Lubik and Schorfeide (2005). The parameter estimates of inverse elasticity of intermporal substitution in consumption $(\sigma)$, the elasticity of intratemporal substitution between a bundle of home goods $(\eta)$ and the inverse of wage elasticity of labour supply $(\varphi)$ are $0.84,1.01,0.98$ respectively. It should also be noted that high value of $(\sigma)$ show that household are more willingness to accept deviation from a uniformed pattern of consumption over time. This high value of inverse elasticity of intermporal substitution in consumption is also consistent with the low value of habit persistence as noted above. These parameter values are not apart from their prior means.

The posterior estimates of Calvo price stickiness provide reasonable notion about frequencies of price change which is the probability of not changing price in a given quarters. The estimated values of $\left(\theta_{H}\right)$ and $\left(\theta_{F}\right)$ are 0.24 and 0.76 respectively, which shows the proportion of firms that do not re-optimize their prices in a given quarters. Furthermore, comparatively lower value of $\left(\theta_{H}\right)$ shows domestic firms re-optimize their prices in a given quarters frequently. These staggered price coefficients imply that the average duration of price contracts is around two quarters for domestic firms and three to four quarters for import retailers. This duration is

\footnotetext{
${ }^{21} \underline{\mathrm{http}}$ ://eemc.jrc.ec.europa.eu// softwareDYNARE-Dowload.htm
} 
calculated as: $1 /(1-\theta)$. These results are also consistent with da Silveira (2006) in the case of Brazil (emerging market economy) and Smets and Wouters (2003) in the case of US.

The posterior estimates of Central Bank reaction function provide a reasonable description of monetary policy design in Pakistan during the sample period. The posterior estimate of inflation coefficient $\left(\phi_{1}\right)$ is 1.17 which is slightly low from its prior mean and output growth coefficient $\left(\phi_{2}\right)$ is 0.72 which is above from its prior mean. This also shows that policy maker in Pakistan put more weight on growth objectives as compared with other developing economies. A recent empirical study by Malik and Ahmed (2007) argued that coefficient values (weights) as suggested by Taylor (1993) are not suitable for Pakistan's monetary policy reaction function. However, our estimated values of monetary policy reaction function are approximately closed to Taylor rule. Finally, the posterior mean for the degree of interest rate smoothing is estimated to be 0.94 which is quite high degree of smoothness as compare with its prior mean. The overall results of reaction function show the effectiveness of monetary policy design in Pakistan with price stability as its primary objective consistent with the economic growth objectives. Finally all posterior estimates with their $95 \%$ confidence interval are available in second column of table B3 in Appendix-B.

\subsection{Parameter Fitness and Stability Results}

Parameter's stability and fitness results are provided in figure-B2 of appendix-B. The d-stat of Smirnov-test is also provided for each parameter, which shows the significance of for individual parameter into the whole model. Furthermore, cumulative plots for stability and instability behavior provide us useful information for the fitness of each structural parameter. Figure B2 shows that all model parameters are stable and properly fitter with respect to the data.

Similar to structural parameters we also assessed the fitness of structural shocks. The d-stat results vis-à-vis cumulative plots show that all structural shocks are fitted but with some degree of instability. This might be due to some degree of seasonality which still exists in the quarterly constructed data.

\subsection{Impulse Response Analysis}

Figure B3 of appendix-B shows the impulse response functions for model endogenous variables in response to the various structural shocks. ${ }^{22}$ These impulse response functions provide several interesting results.

First figure plots the impulse response to positive domestic labour productivity shock. Following this shock, domestic output initially increases up to two quarters and decrease slightly before staying above trend until eight quarters later. The later decrease in output shows that agent's substitution between working and leisure dominates the lower cost of production

\footnotetext{
22 The impulse responses to a one unit increase in the various structural shocks are calculated using 10,000 random draws from the posterior distribution of the model parameters. Initially we draw posterior distributions using 1.5 million Markov chains. But for impulse responses we use only limited random draws due to computational complexity.
} 
that arises from the increase in productivity. Secondly consumption falls initially up to one quarter then increases but increment is steady and almost around its steady path. Inflation on the other hand falls initially as the higher labour productivity supports to minimize the cost of production before returning close to steady state eight quarters later. ${ }^{23}$ All other variables fall initially and returning close to zero up to four to six quarters later.

Second figure plots the impulse response to a positive domestic inflation shock. ${ }^{24}$ Following this shock, domestic output initially fall, up to two quarters and then returning close to its steady state four to six quarters later. Secondly consumption also falls initially up to one quarter but its decline magnitude is relatively less as compared with domestic output. This also shows that high inflation in Pakistan do not hit domestic consumption significantly. Thirdly, positive shock in domestic inflation decreases the degree of domestic competitiveness. Furthermore, the central bank of Pakistan responds to the higher rate of inflation by increasing the interest rate by 100 to 200 basis points. In response to this monetary tightening domestic output decreasing up to one to two quarters but this decline impact is very nominal. Exchange rate on the other hand appreciates in response to positive domestic supply shock.

Third figure plots the impulse response to a positive imported inflation shock. The impact of this shock on the model endogenous variables is quite different as compared with domestic inflation or supply shock. In response to this shock domestic inflation increases, as higher import prices pushing up the cost of production causes as a surge in domestic inflation. Term of trade increases as foreign prices increases relative to domestic prices. The economic interpretation of this surge in the degree of competiveness is that domestic agents substitute out of foreign produced goods into home produced goods in response to import inflation shock which causes expenditure switching effect and hence leads to a surge in domestic terms of trade. The central bank of Pakistan responds to the higher rate of imported inflation by increasing the interest rate by 150 to 250 basis points as compared with domestic inflation case. This also leads an exchange rate appreciation but this appreciation is higher than in the case of domestic inflation.

Forth figure plots the impulse response to a positive interest rate shock which also considered as a domestic monetary policy shock. Following the increase in the interest rate, domestic inflation, imported inflation, degree of international competitiveness and domestic output decreases; exchange rate appreciates before returning to equilibrium. Consumption on the other hand increases by one percent and returning close to its steady state up to four to six quarters. These results reasonably capture the effectiveness of monetary policy as it shows to achieve its basic objectives, with some nominal tradeoffs, in terms of output decline and exchange rate appreciation. Furthermore, due to continuous domestic supply and foreign price shocks there needs to further tightening of monetary is order to curb these frights.

\footnotetext{
${ }^{23}$ In this case, the monetary authority can afford to loosen monetary policy to bring inflation back to zero.

${ }^{24}$ As inflation dynamics modeled with the New Keynesian Philips Curve, so this shock is also considered as a supply shock.
} 
Fifth figure plots the impulse response to a positive exchange rate shock. This shock transmits from uncovered interest parity condition ${ }^{25}$ to rest of the model. In response to this shock domestic inflation, output, interest rate decreases but the decrement impact in all the variables is very nominal. For monetary policy perspective, interest rates decline by 50 basis points. This also indicates a monetary expansion in the case of surge in UIP condition. ${ }^{26}$ Lastly, this shock decreases the degree of international competitiveness and increases consumption up to six and two percent respectively.

Sixth figure plots the impulse response to a positive term of trade shock. Following this shock, all variables show a minor surge except imported inflation which shows a decline behavior and return to zero up to four quarters later. This shock also causes an exchange rate appreciation. Lastly for monetary policy perspective, interest rate shows a positive response to this shock up to 10 basis points and then returns to its equilibrium path up to two quarters later. This small monetary tightening helps to offset the adverse impact in term of domestic inflation and exchange rate appreciation.

Final two figures show impulse responses to a positive foreign output shock and foreign monetary policy shock. Due to these positive shocks, all domestic endogenous variables behave according to the theory. This also represents the effectiveness of model, which is quite useful for policy decision making.

\footnotetext{
25 Adolfson et al. (2008) noted that the uncovered interest rate parity (UIP) condition is a key equation in open economy DSGE models. It shows the difference between domestic and foreign nominal interest rates equals the expected future change in the nominal exchange rate. The UIP condition is a key equation in open economy models not only for the exchange rate but also for many macroeconomic variables, since there is a lot of internal propagation of exchange rate movements working through fluctuating relative prices. There is, however, strong empirical evidence against the standard UIP condition, see for instance, e.g., Eichenbaum and Evans, (1995); Faust and Rogers, (2003). Moreover, a DSGE model with a standard UIP condition cannot account for the so-called 'forward premium puzzle' recorded in the data, i.e. that a currency whose interest rate is high tends to appreciate which implies that the risk premium must be negatively correlated with the expected exchange rate depreciation see, e.g., Fama, (1984); Froot and Frankel (1989).

26 Figure A4 of appendix-A, plots the residuals of uncovered interest rate parity (UIP) condition generated from Pakistan's data by utilizing theory based and regression based methodologies, see, Lubik and Schorfeide (2005) for further detail. This figure also provides a historical description of monetary expansion and tightness in the case of surge and decline in UIP. The recent negative values of UIP show the tight monetary policy stance which is in line with the standard macroeconomic theory.
} 


\section{Conclusion}

In this paper, we estimate a small open economy DSGE model for Pakistan. The model setup is based on new Keynesian framework characterized by nominal rigidity in prices with habit formation in household's consumption. This framework allows us to include microeconomic foundations of optimum behavior of the economic agents; domestic households, domestic firms, monetary authority and foreign sector economy, into the system. It is also considered that the foreign sector is completely exogenous to the system. In our empirical section, some parameters has been calibrated, e.g., degree of openness, discount factor, inverse elasticity of intertemporal substitution; the remaining parameters has been estimated using the Bayesian simulation approach, which combines prior information from preliminary estimates and from historical data covering period 1984:Q1 to 2007:Q4. The model ability to describe the dynamic structure of Pakistan economy has been analyzed by means of impulse-response functions.

The estimation results of structural parameters and model impulse response functions yield useful quantitative vis-à-vis qualitative information. The exogenous shocks impact on endogenous system variables in the right direction, so that the model seems to be helpful as a complementary tool for monetary policy analysis in the Pakistan economy.

From several interesting results, few are; (a) high inflation in Pakistan do not hit domestic consumption significantly; (b) Central bank of Pakistan responds to high inflation by increasing the policy rate by 100 to 200 bps; (c) exchange rate appreciates in both the cases of high domestic and imported inflation; (d) tight monetary policy stance helps to curb domestic inflation as well as imported inflation but appreciates exchange rate significantly (f) pass through of exchange rate to domestic inflation is very low; finally parameter value of domestic price stickiness shows that around 24 percent domestic firms do not re-optimize their prices which implies averaged price contract is about two quarters.

Finally, this model is still in progress. After relaxing some key assumptions and incorporating fiscal-side dynamics, this model will be more robust for policy decision making and future forecasting of key macroeconomic variables. 


\section{Appendix-A}

Table A1: Description of Variables

\begin{tabular}{c|c|l}
\hline \hline S. No & Variable* & Description / Source \\
\hline 1 & $y_{\mathrm{t}}$ & $\begin{array}{l}\text { Quarterly real GDP per capita as a proxy of domestic output. We follow } \\
\text { Kemal and Arby (2004) to construct this series. We initially convert original } \\
\text { series into new base (Year 2000=100). Since it is an interpolated series from } \\
\text { annual frequency data, so we also perform necessary seasonal adjustments } \\
\text { using moving average methodology. Finally, for stationarity purpose we } \\
\text { detrend this series from its linear trend. }{ }^{* *}\end{array}$ \\
\hline 2 & $\pi_{\mathrm{t}}$ & $\begin{array}{l}\text { Overall domestic inflation. This series is the annual growth rates in consumer } \\
\text { price index (CPI) for Pakistan. Data source of this variable is FBS, Islamabad, } \\
\text { Pakistan. }\end{array}$ \\
\hline 3 & $\pi_{\mathrm{F}, \mathrm{t}}$ & $\begin{array}{l}\text { Imported Inflation as a proxy of foreign inflation. This series is the annual } \\
\text { growth rates in unit value of import index (UVIM). This series is taken from } \\
\text { IFS-CD June 2008 version. }\end{array}$ \\
\hline 5 & $\mathrm{q}_{\mathrm{t}}$ & $\begin{array}{l}\text { Real exchange rate. This series is calculated by multiplying nominal exchange } \\
\text { rate with Pak-US price ratios where CPI of both countries is a suitable proxy of } \\
\text { respected prices. Data source of this variable is IFS-CD June 2008 version. }\end{array}$ \\
\hline 7 & $\mathrm{r}_{\mathrm{t}}$ & $\begin{array}{l}\text { Nominal interest rate. Short term money market rate is taken as the proxy of } \\
\text { nominal interest rate. Data source of this variable is Statistical Bulletins of the } \\
\text { State Bank of Pakistan. }\end{array}$ \\
\hline $\mathrm{y}_{\mathrm{t}}{ }^{*}$ & $\mathrm{r}_{\mathrm{t}}^{*}$ & $\begin{array}{l}\text { Term of Trade (ToT). This series is calculated by taking the ratio of the unit } \\
\text { value of import index (UVIM) and unit value of export index (UVEX). Data } \\
\text { source of this series is IFS-CD June 2008 version. }\end{array}$ \\
\hline $\begin{array}{l}\text { Foreign Output. The series is taken as annual growth rate in U.S. real GDP per } \\
\text { capita. This is obtained from IFS-CD June 2008 version. }\end{array}$ \\
\hline $\begin{array}{l}\text { Foreign real interest rates. This series is calculated by subtracting nominal US } \\
\text { money market rates from expected inflation. Data source of this variable is } \\
\text { IFS-CD June 2008 version. }\end{array}$ \\
\hline
\end{tabular}

${ }^{*}$ For stationary purpose, all series are converted into detrended form. This is done by subtracting each series from its linear trend. **Detrended output is also considered as a proxy of output gap, see for instance, Bukhari and khan (2008).

Table A2: Pairwise Correlation Matrix

\begin{tabular}{|c|c|c|c|c|c|c|c|c|}
\hline & $\mathrm{y}_{\mathrm{t}}$ & $\mathrm{y}_{\mathrm{t}}^{*}$ & $\pi_{\mathrm{t}}$ & $\pi_{\mathrm{F}, \mathrm{t}}$ & $\mathrm{r}_{\mathrm{t}}$ & $\mathrm{r}_{\mathrm{t}}^{*}$ & $\mathrm{q}_{\mathrm{t}}$ & $\mathrm{s}_{\mathrm{t}}$ \\
\hline $\mathrm{y}_{\mathrm{t}}$ & 1.00 & & & & & & & \\
\hline$y_{t}^{*}$ & 0.23 & 1.00 & & & & & & \\
\hline$\pi_{\mathrm{t}}$ & -0.05 & 0.18 & 1.00 & & & & & \\
\hline$\pi_{\mathrm{F}, \mathrm{t}}$ & -0.05 & 0.28 & 0.08 & 1.00 & & & & \\
\hline$r_{t}$ & -0.28 & -0.12 & 0.11 & -0.13 & 1.00 & & & \\
\hline$r_{t}^{*}$ & -0.16 & 0.06 & 0.05 & 0.08 & 0.58 & 1.00 & & \\
\hline $\mathrm{q}_{\mathrm{t}}$ & -0.21 & -0.31 & -0.75 & -0.07 & -0.17 & -0.10 & 1.00 & \\
\hline $\mathrm{s}_{\mathrm{t}}$ & -0.06 & 0.02 & -0.24 & -0.28 & 0.46 & 0.49 & 0.21 & 1.00 \\
\hline
\end{tabular}


FigureA1: Frequency of Price Change of various commodities
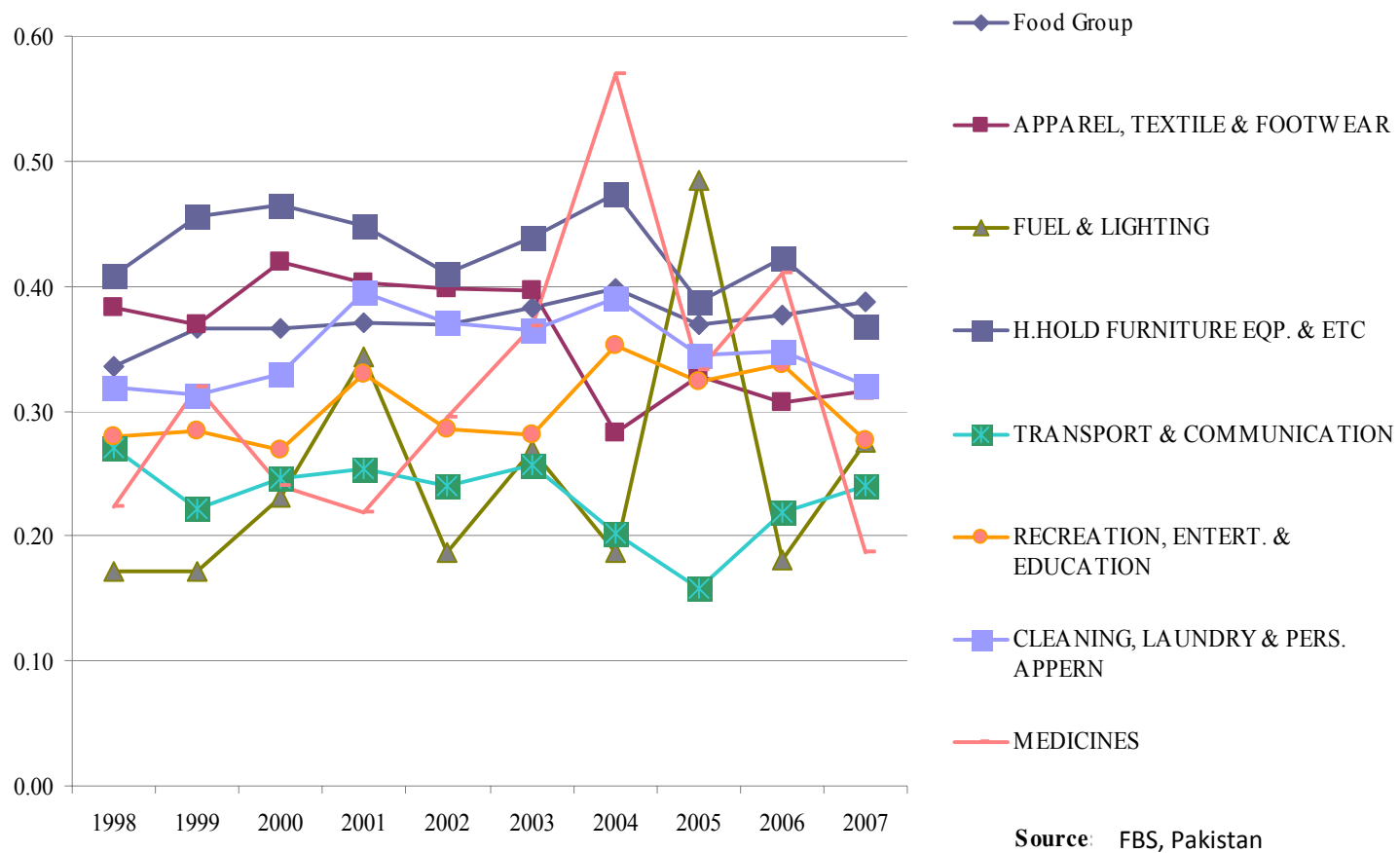

*Figure key: Author's calculations based on commodity price data.

Figure A2: Average Frequency of Price Change

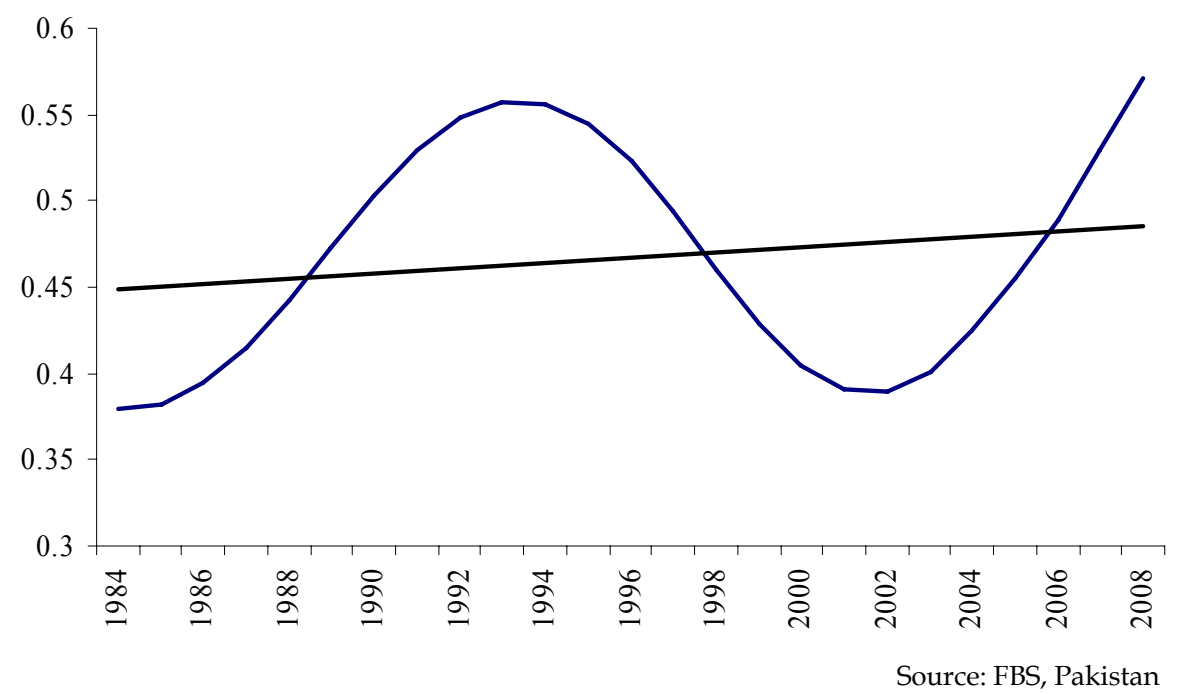

${ }^{*}$ Figure key: The parameter value $\theta_{H}=0.5$ is taken as prior which is the average price stickiness. 
Figure A3: Degree of Openness

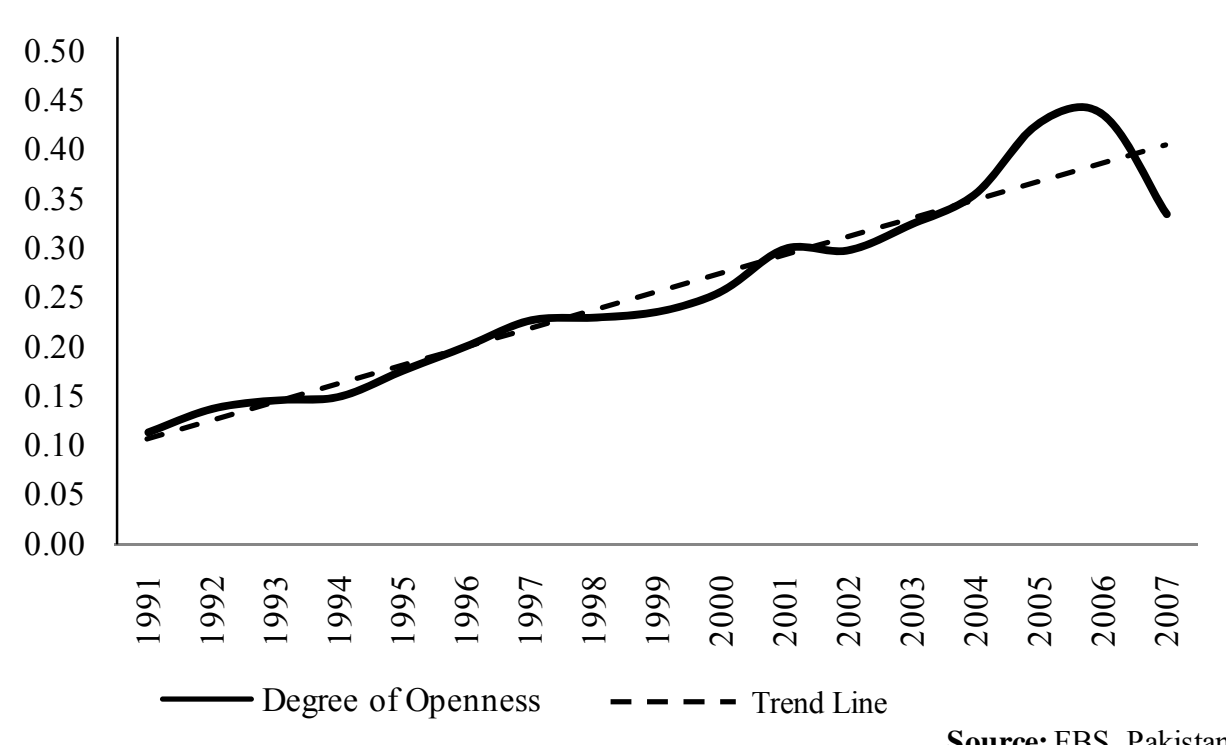

*Figure key: The parameter value $\alpha=0.35$ is taken as prior which is the average degree of openness

Figure A4: Uncovered Interest Parity Condition Residuals

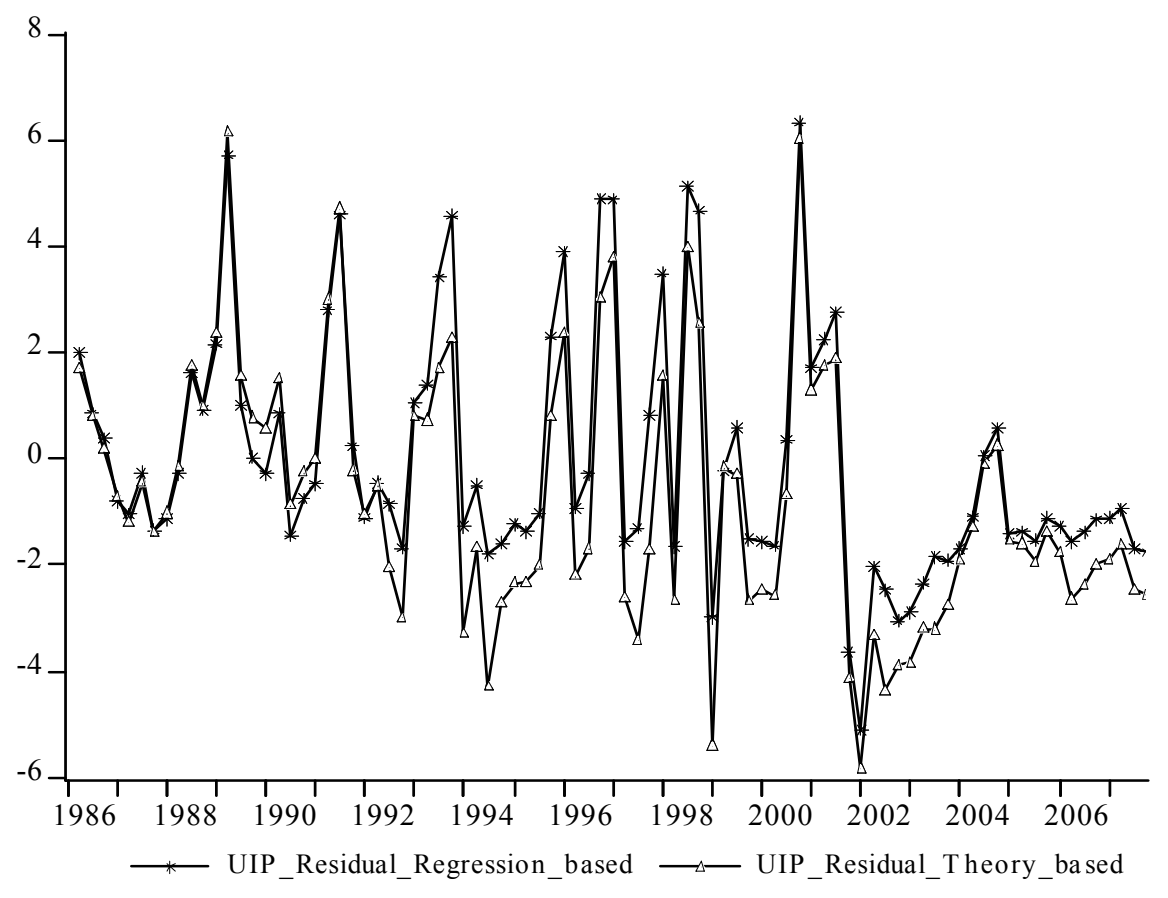

${ }^{*}$ Figure key: Both residuals approximately follow the same path 


\section{Appendix-B}

B1. Log-Linearization and canonical representation of the model

This section proceeds by a model solution methodology with the log-linearization and canonical representation of the model along with its foreign sector economy. ${ }^{27}$ In order to solve the model, we first state the first order nonlinear dynamic system that characterizes the competitive equilibrium. In order to calculate the steady state we transform the system equations into their deterministic steady state representation and solve using numerical methods. Then we loglinearize around the deterministic steady state where $\tilde{x}_{t}=\log \left(x_{t}\right)-\log (\bar{x})$. At this stage the system is expressed in terms of relative deviations from the steady state. After solving the model using the method of Klein (2000) ${ }^{28}$ we obtain matrices $M$ and $H$ which generate the dynamic solution by iterating on the following two equations:

$$
\begin{aligned}
& Y_{t}=H x_{t} \\
& x_{t+1}=M x_{t}+R \eta_{t+1}
\end{aligned}
$$

Where $Y$ is a vector composed by control, co-state and flow variables, $x$ is a vector of endogenous and exogenous states, $H$ characterizes the policy function and $M$ the state transition matrix. $\eta_{t+1}$ is an innovation vector and $R$ is a matrix composed of zeros, ones or a parameter instead of a one. This matrix determines which variables are hit by the shock and in what magnitude. Given a set of values of the parameters of the model, this state space representation will help us to compute the relevant statistics of the model such as the spectrum of the data, the likelihood function, among others.

The small open economy model consists of eleven equations for endogenous variables and three equations for the exogenous processes.

Table B1: Description of model endogenous and exogenous variables

\begin{tabular}{c|l|l}
\hline 1. & List of endogenous variables: & $\left\{\mathrm{y}_{\mathrm{t}} ; \mathrm{y}_{\mathrm{t}}^{*} ; \pi_{\mathrm{t}} ; \pi_{\mathrm{F}, \mathrm{t}} ; \mathrm{r}_{\mathrm{t}} ; \mathrm{r}_{\mathrm{t}}^{*} ; \mathrm{q}_{\mathrm{t}}\right\}$ \\
\hline 2. & List of endogenous state variables: & $\left\{\psi_{t} ; c_{\mathrm{t}} ; m c_{\mathrm{t}} ; \pi_{\mathrm{H}, \mathrm{t}} ; \mathrm{s}_{\mathrm{t}}\right\}$ \\
\hline 3. & List of model endogenous innovations & $\left\{a_{\mathrm{t}} ; v_{t}^{\pi_{H}} ; v_{t}^{\pi_{H}} ; v_{t}^{\pi_{F}} ; v_{t}^{r} ; v_{t}^{r^{*}} ; v_{t}^{q} ; v_{t}^{s}\right\}$ \\
\hline 4. & List of model exogenous shocks: & $\left\{v_{t}^{a} ; v_{t}^{y^{*}} ; v_{t}^{r^{*}}\right\}$ \\
\hline
\end{tabular}

The canonical representation of the whole model in log-linearized form is available in table B2.

27 The foreign sector economy consists of two main equations; (a) output and (b) real interest rate as a proxy of foreign monetary policy instrument. This sector is assumed to be completely exogenous to the small open economy, Pakistan.

${ }^{28}$ Any other method can also be used to solve the log-linear approximation to the rational expectations solution, e.g., Sims (2002). 
Table B2: Canonical Representation of the Model

\begin{tabular}{|c|c|c|}
\hline S. No. & Description: & Model Log-Linearized Equation(s): \\
\hline 1. & $\begin{array}{l}\text { Goods market clearing } \\
\text { condition: }\end{array}$ & $y_{t}=(2-\alpha) \alpha \eta s_{t}+(1-\alpha) c_{t}+\alpha \eta \psi_{t}+\alpha y_{t}^{*}$ \\
\hline 2. & Firm Marginal Cost: & $m c_{t}=\varphi y_{t}+\alpha s_{t}+\frac{\sigma}{1-h}\left(c_{t}-h c_{t-1}\right)-(1+\varphi) a_{t}$ \\
\hline 3. & Domestic Inflation: & $\pi_{H, t}=\beta\left(1-\theta_{H}\right) E_{t}\left\{\pi_{H, t+1}\right\}+\theta_{H} \pi_{H, t-1}+\lambda_{H} m c_{t}+v_{t}^{\pi_{H}}$ \\
\hline 4. & Imported Inflation: & $\pi_{F, t}=\beta\left(1-\theta_{F}\right) E_{t}\left\{\pi_{F, t+1}\right\}+\theta_{F} \pi_{F, t-1}+\lambda_{F} \psi_{F, t}+v_{t}^{\pi_{F}}$ \\
\hline 5. & Overall Inflation: & $\pi_{t} \equiv\left[(1-\alpha) \pi_{H, t}+\alpha \pi_{F, t}\right]$ \\
\hline 6. & $\begin{array}{l}\text { Monetary Policy Reaction } \\
\text { Function: }\end{array}$ & $r_{t}=\rho_{r} r_{t-1}+\left(1-\rho_{r}\right)\left(\phi_{1} \tilde{\pi}_{t}+\phi_{2} \Delta \tilde{y}_{t}\right)+v_{t}^{r}$ \\
\hline 7. & $\begin{array}{l}\text { Uncovered Interest Parity } \\
\text { Condition: }\end{array}$ & $E_{t} \Delta q_{t+1}=-\left(r_{t}-\pi_{t+1}\right)-\left(r_{t}^{*}-\pi_{t+1}^{*}\right)+v_{t}^{q}$ \\
\hline 8. & $\begin{array}{l}\text { Term of Trade with } \\
\text { Measurement Error: }\end{array}$ & $s_{t}=s_{t-1}+\tilde{\pi}_{F, t}-\tilde{\pi}_{H, t}+v_{t}^{s}$ \\
\hline 9. & Law of one price gap: & $\tilde{\psi}_{t}=-q_{t}-(1-\alpha) s_{t}$ \\
\hline 10. & Consumption Euler Equation: & $E_{t}\left(c_{t+1}-h c_{t}\right)-\left(\frac{1-h}{\sigma}\right)\left(r_{t}-E_{t} \pi_{t+1}\right)=c_{t}-h c_{t-1}$ \\
\hline 11. & $\begin{array}{l}\text { International Risk Sharing } \\
\text { Condition: }\end{array}$ & $y_{t}^{*}-h y_{t-1}^{*}-\left(\frac{1-h}{\sigma}\right) q_{t}=c_{t}-h c_{t-1}$ \\
\hline 12. & Exogenous Processes: & $\begin{array}{l}a_{t}=\rho_{a} a_{t-1}+v_{t}^{a} \\
y_{t}^{*}=\lambda_{1} y_{t-1}^{*}+v_{t}^{y^{*}} \\
r_{t}^{*}-E_{t} \pi_{t+1}^{*}=\rho_{r^{*}}\left(r_{t}^{*}-E_{t} \pi_{t}^{*}\right)+v_{t}^{r^{*}}\end{array}$ \\
\hline
\end{tabular}

*Table Key: All exogenous processes follow recursive equilibrium law of motion. 
Table B3: Model Prior and Posterior Distribution Results

\begin{tabular}{llllllll}
\hline \hline & \multicolumn{3}{c}{ Prior Distributions } & \multicolumn{4}{c}{ Posterior Distribution } \\
\cline { 2 - 6 } Parameters & Distribution & Mean & Std_Dev & Distribution & Mean & 5\% Percentile & 95\% Percentile \\
\hline \hline alpha & beta & 0.35 & 0.20 & beta & 0.23 & 0.19 & 0.24 \\
h & beta & 0.50 & 0.20 & beta & 0.36 & 0.33 & 0.37 \\
sigma & normal & 1.00 & 0.40 & normal & 0.84 & 0.80 & 0.86 \\
eta & gamma & 1.00 & 0.40 & gamma & 1.01 & 1.00 & 1.08 \\
phi & gamma & 1.00 & 0.40 & gamma & 0.98 & 0.91 & 1.04 \\
thetah & beta & 0.50 & 0.25 & beta & 0.24 & 0.21 & 0.36 \\
thetaf & beta & 0.50 & 0.25 & beta & 0.76 & 0.68 & 0.82 \\
phi1 & gamma & 1.50 & 0.25 & gamma & 1.17 & 1.10 & 1.23 \\
phi2 & gamma & 0.25 & 0.10 & gamma & 0.72 & 0.65 & 0.78 \\
rhor & beta & 0.50 & 0.20 & beta & 0.94 & 0.87 & 1.00 \\
rhorst & beta & 0.50 & 0.20 & beta & 0.43 & 0.36 & 0.49 \\
rhoa & beta & 0.50 & 0.20 & beta & 0.51 & 0.44 & 0.57 \\
lam1 & beta & 0.50 & 0.20 & beta & 0.36 & 0.29 & 0.42 \\
sig_a & normal & 2.00 & 0.50 & normal & 2.04 & 1.98 & 2.11 \\
sig_s & normal & 2.00 & 0.50 & normal & 1.92 & 1.86 & 1.99 \\
sig_q & normal & 2.00 & 0.50 & normal & 2.04 & 1.98 & 2.11 \\
sig_pi & normal & 2.00 & 0.25 & normal & 2.02 & 1.96 & 2.09 \\
sig_pif & normal & 1.00 & 0.20 & normal & 1.62 & 1.56 & 1.69 \\
sig_r & normal & 1.00 & 0.20 & normal & 1.28 & 1.22 & 1.35 \\
sig_rst & normal & 0.50 & 0.20 & normal & 0.50 & 0.44 & 0.57 \\
sig_yst & normal & 1.00 & 0.20 & normal & 1.63 & 1.57 & 1.70 \\
\hline Tabl Key: & & & & & & & \\
\end{tabular}

Table Key:

a/ The posterior mean of all the estimation parameters are delivered by a 150,000 runs of Metropolis-Hastings algorithm.

b/ We use two MATLAB toolboxes; Dynare 4.0 and Uhlig toolkit version 4.1 to estimate our model. Both toolkits are freely available on internet. ${ }^{29}$

c/ The parameter beta which is discount factor is fixed at 0.95 .

${ }^{29}$ Dynare 4.1 toolbox can be download from: $h$ ttp://www.cepremap.cnrs.fr/ michel/dynare/

Uhlig toolkit 4.1 can be download from: http://www2.wiwi.hu-berlin.de/wpol/html/toolkit/version4_1.html 
Figure B1: Model Prior and Posterior Distribution Plots
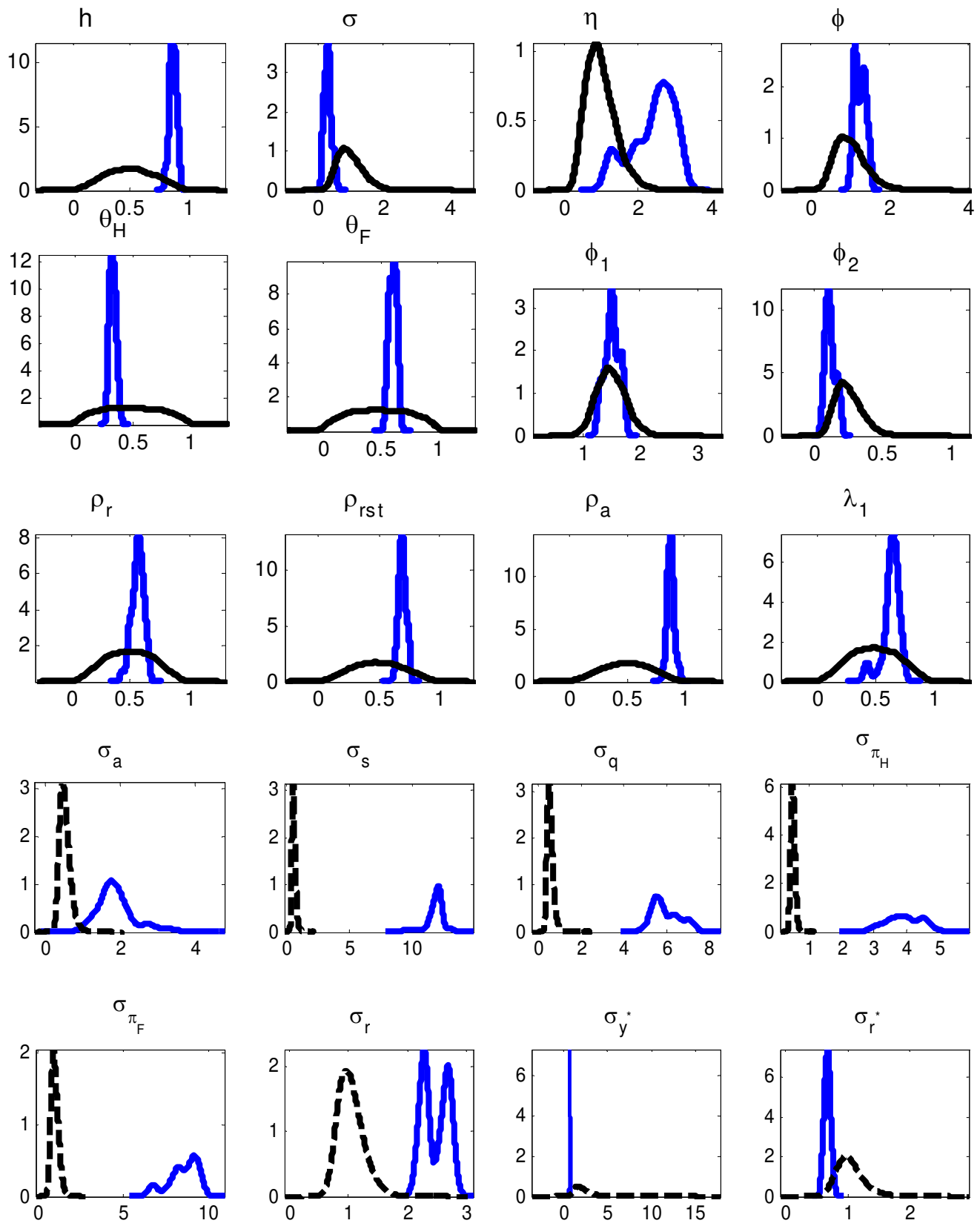

[ _ . Prior Distribution Plot Posterior Distribution Plot 
Figure B2: Smirnov test for Model Parameter Stability

(a) Stability Plots for Model Structural Parameter
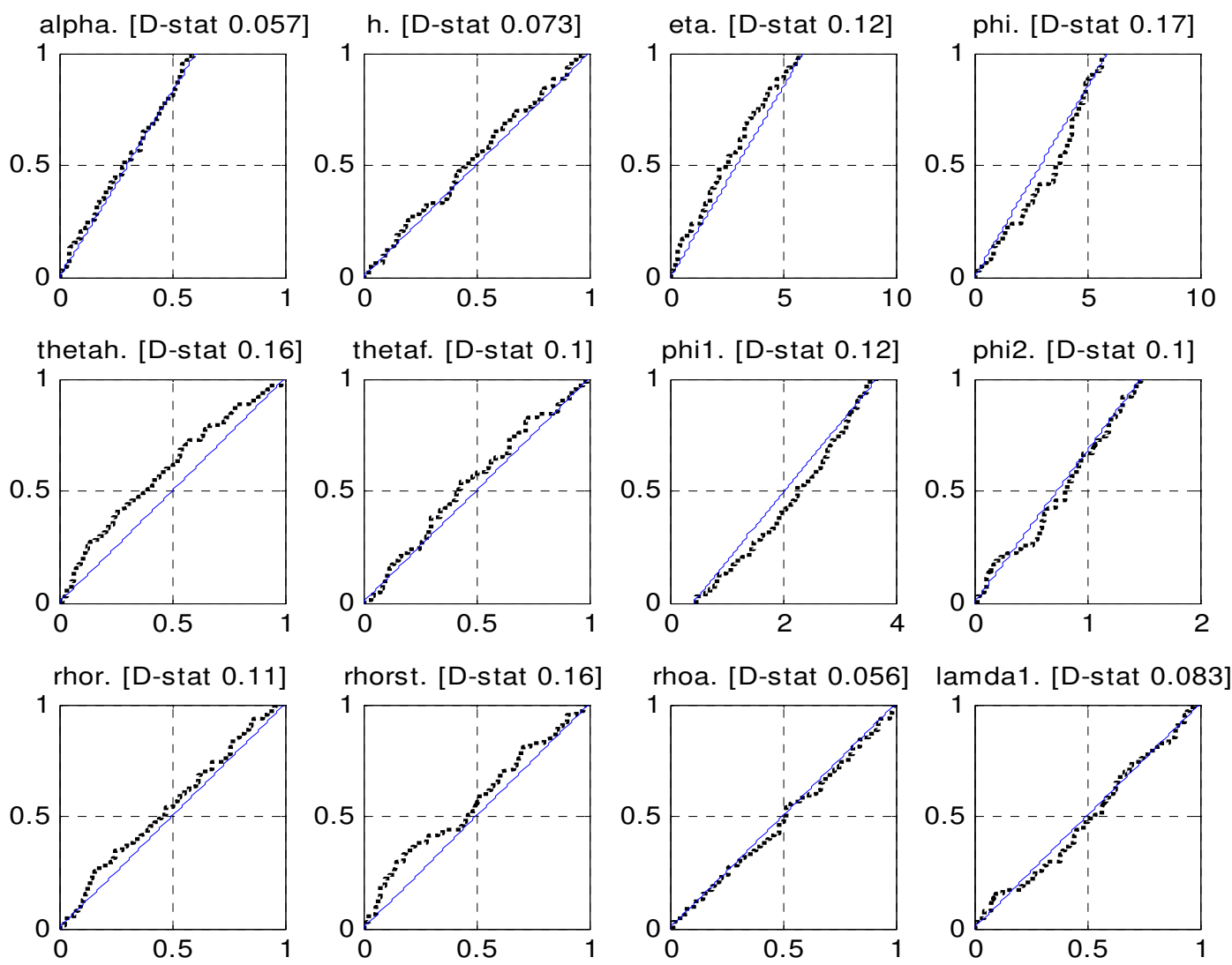

(b) Stability plots for Model Structural Shocks

sigma_a. [D-stat 0.33] sigma_s. [D-stat 0.23] sigma_q. [D-stat 0.18] sigma_pi. [D-stat 0.15]
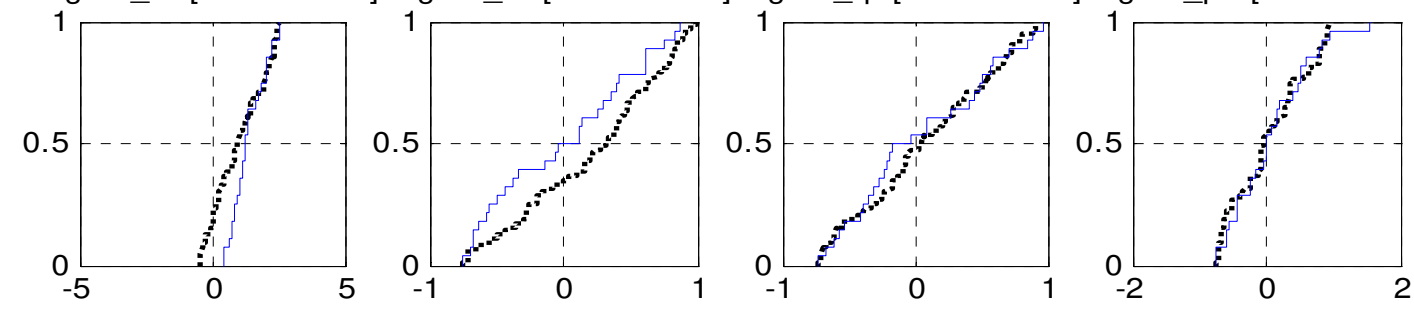

simga_pif. [D-stat 0.18] sigma_r. [D-stat 0.17]sigma_rst. [D-stat 0.22\$igma_yst. [D-stat 0.19]
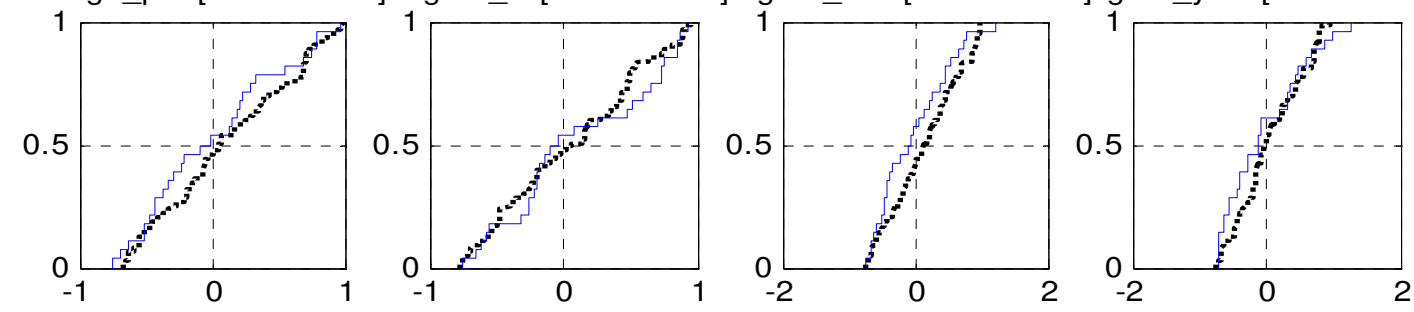

.............. Cumulative distribution of unstable parameter behavior

Cumulative distribution of stable parameter behavior 
Figures B3: DSGE Model Impulse-responses Functions
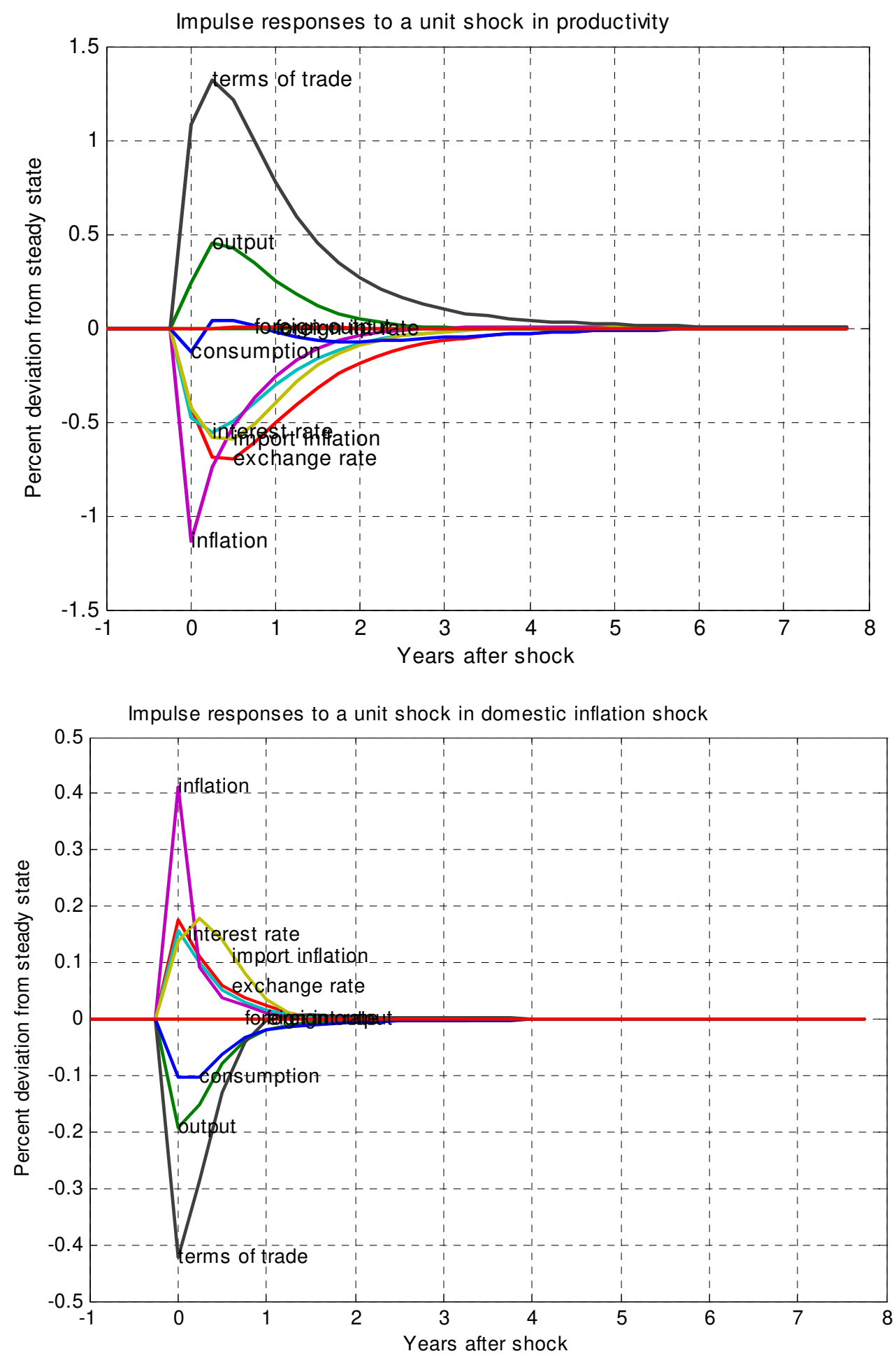

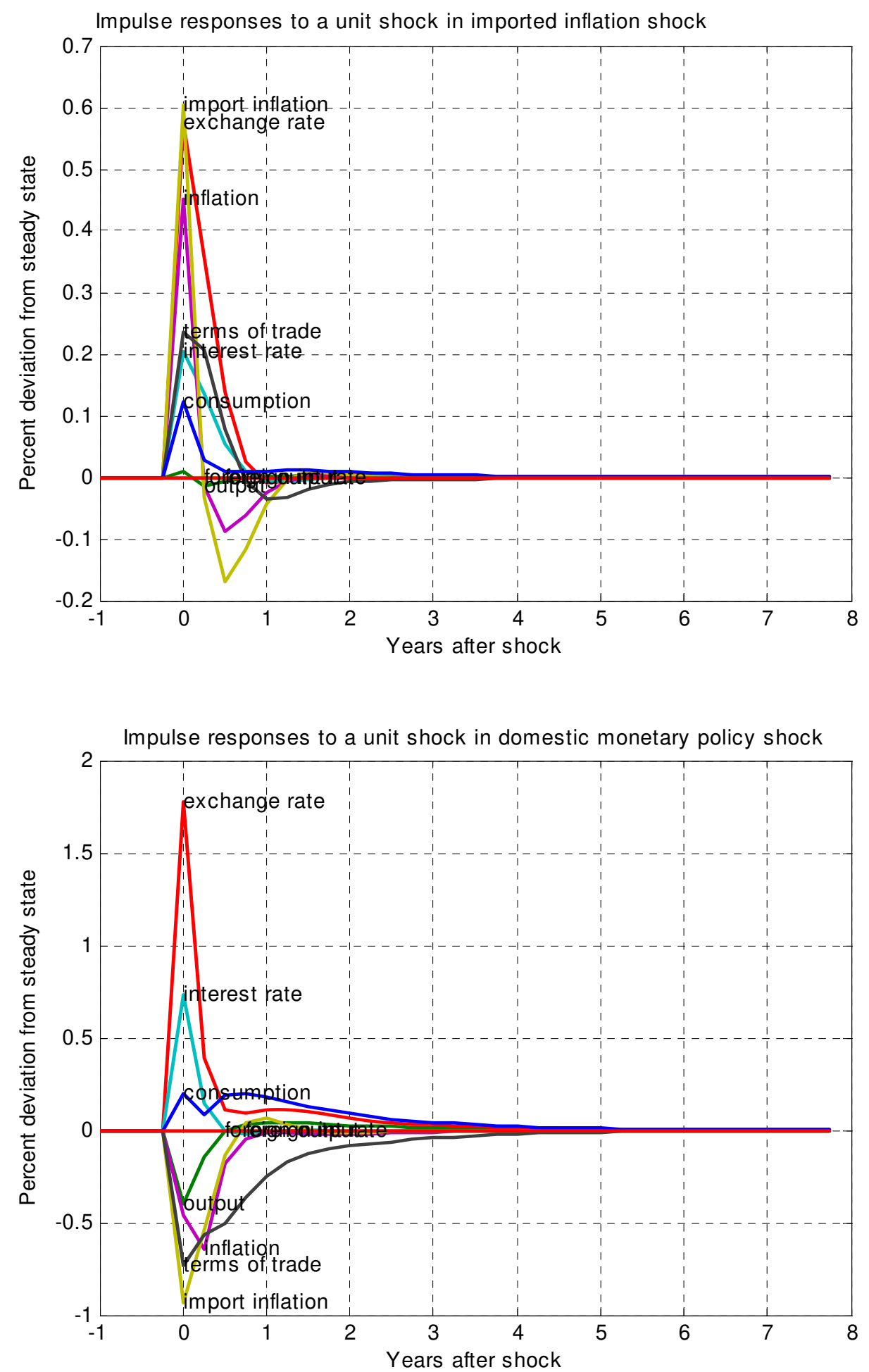

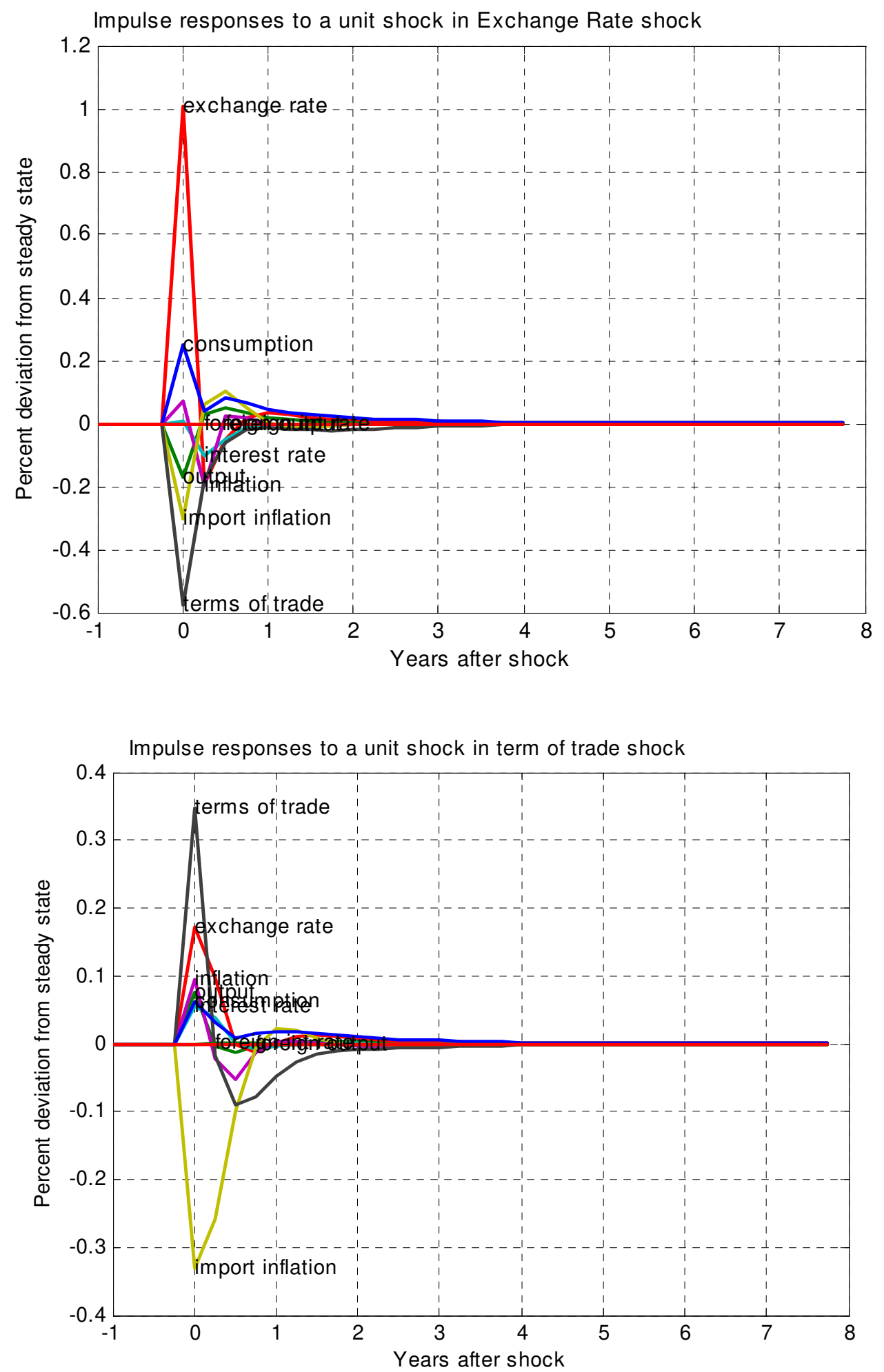

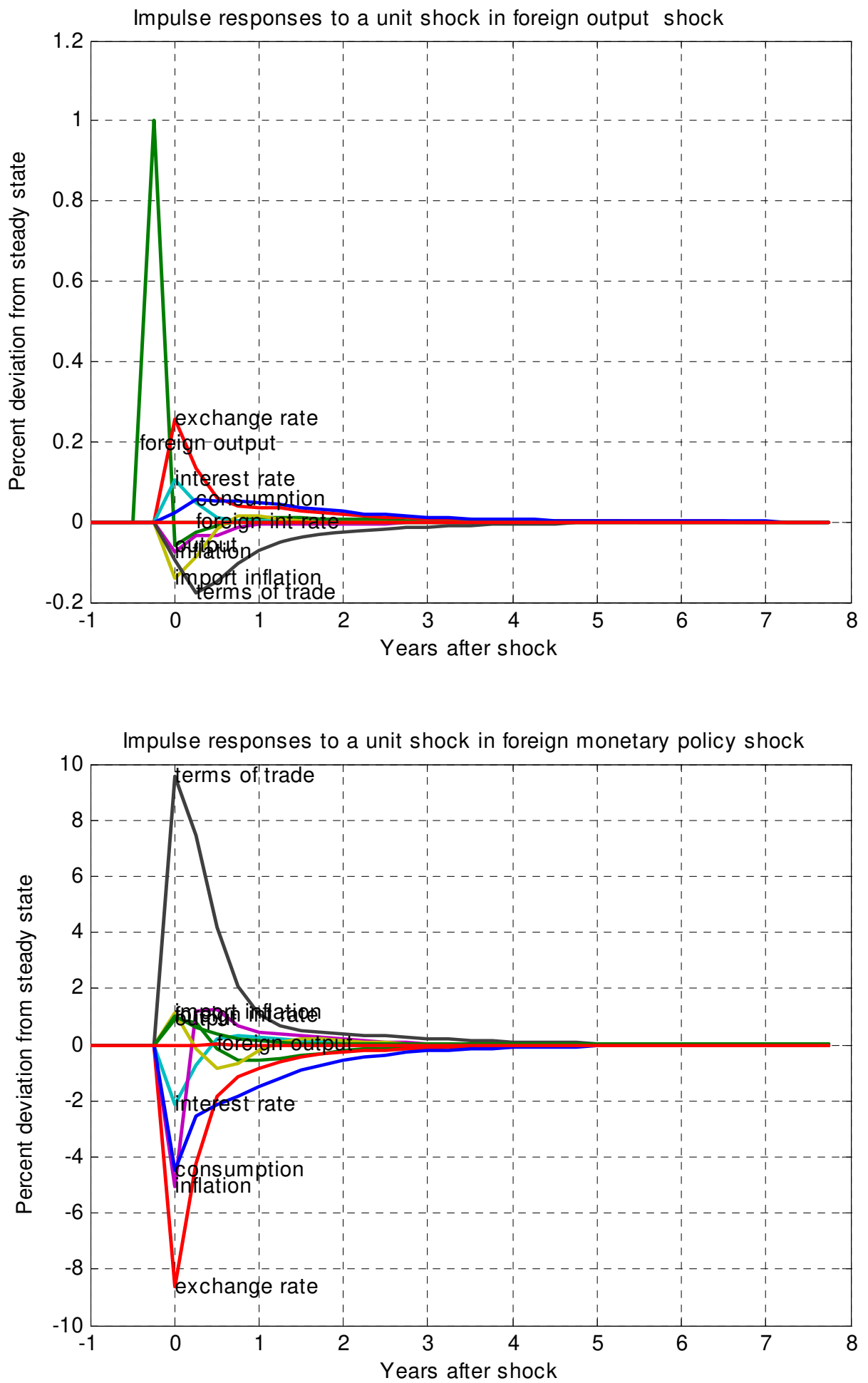
Figure B4: Historical Smoothed Variables ${ }^{30}$
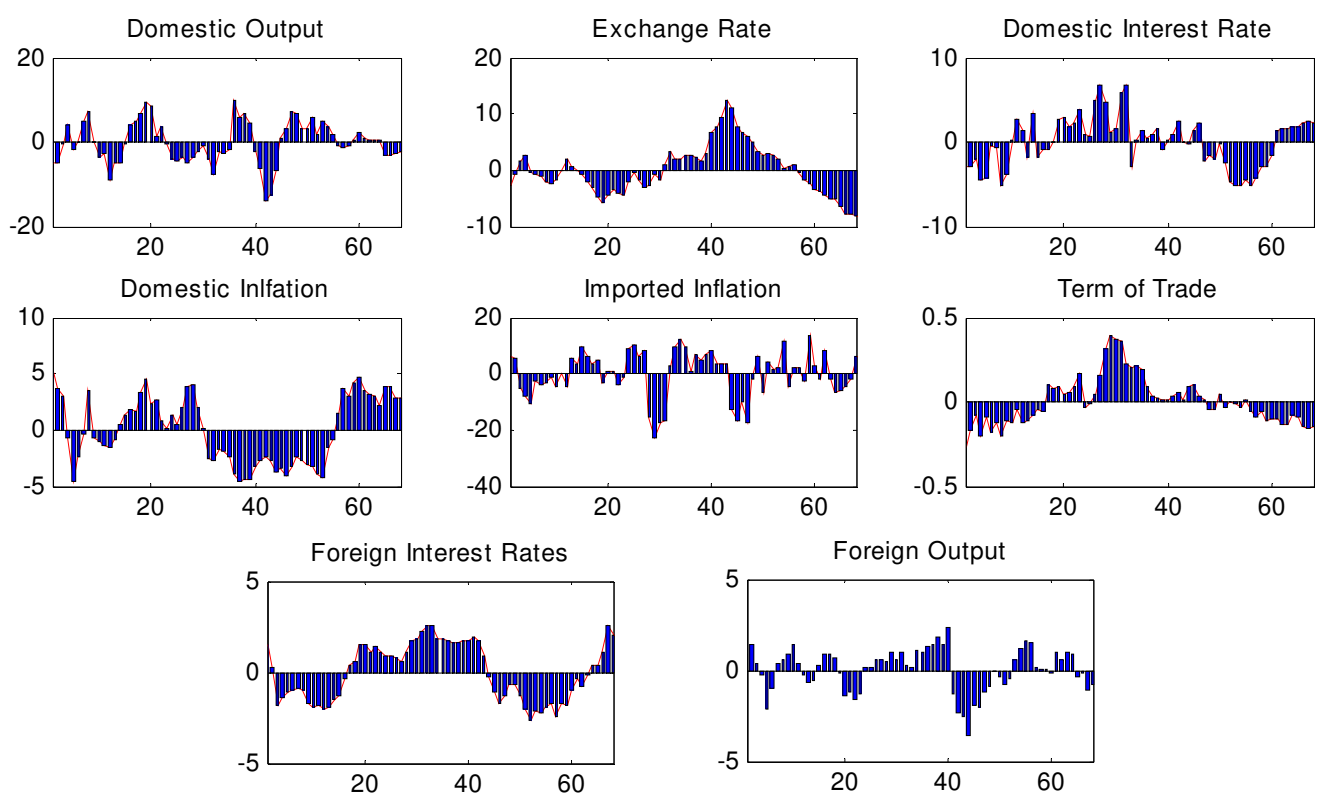

Figure B5: Smoothed Shocks
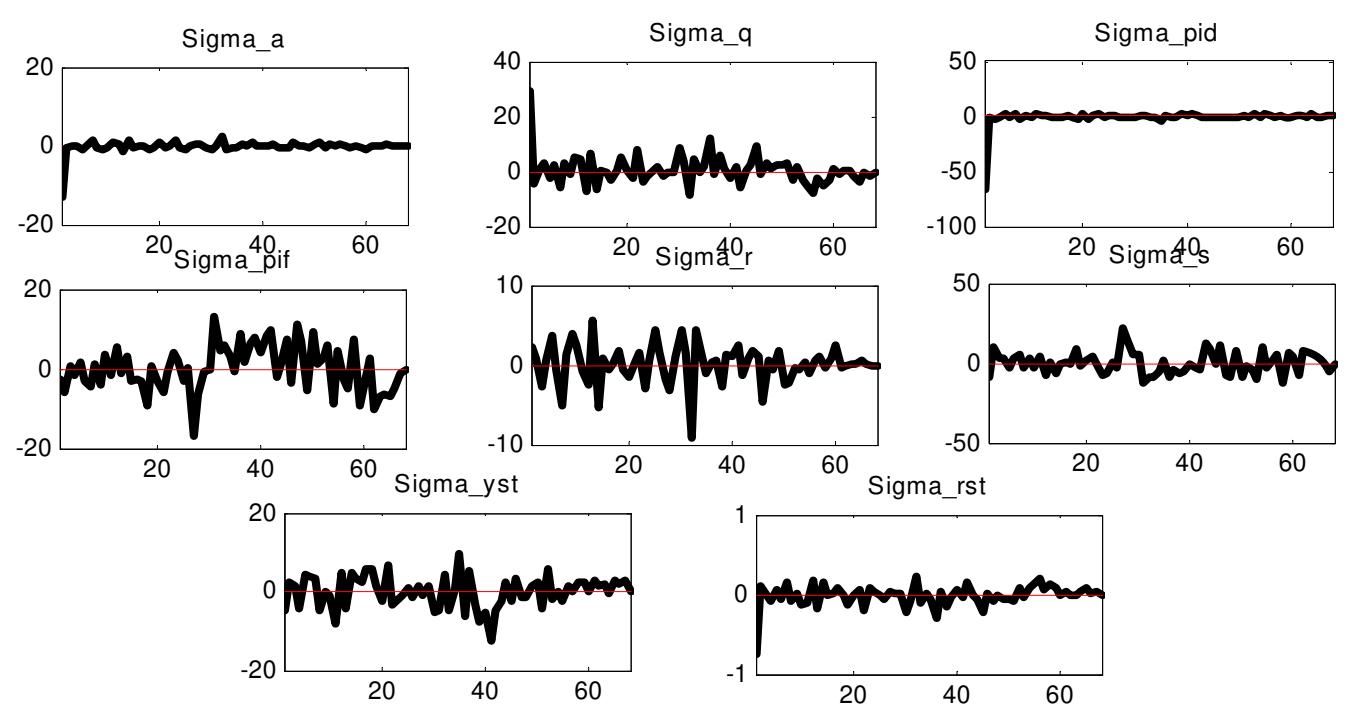

\footnotetext{
${ }^{30}$ Both Figures B3 and B4 summarize the historical smoothness of model variable and shocks. The smoothness is based on the best estimates of the model parameters and helps understanding how the model interprets specific movements in the observed data series.
} 


\section{Appendix-C}

\section{Table C1: A Quick View of Empirical Evidence on DSGE Model}

\begin{tabular}{|c|c|c|c|c|c|}
\hline Country & Authors & Model Description & Data Description & Estimating Technique & Concluding Remarks \\
\hline $\begin{array}{l}\frac{\pi}{0} \\
\text { đే } \\
\tilde{\pi}\end{array}$ & $\begin{array}{l}\text { Dib, } \\
\text { Gammoudi } \\
\text { and Moran } \\
(2008)\end{array}$ & $\begin{array}{l}\text { This study develops on the } \\
\text { basis of New Keynesian } \\
\text { model for Canada. This } \\
\text { model in particular computes } \\
\text { out of sample forecasts and } \\
\text { compares its forecasts with } \\
\text { those arising from VAR } \\
\text { models. It shows that the } \\
\text { forecasts are favorably valid } \\
\text { with that of the benchmark, } \\
\text { particularly as the forecasting } \\
\text { horizon increases. Thus the } \\
\text { study deduces that the model } \\
\text { could become a useful } \\
\text { forecasting tool for Canadian } \\
\text { economy. }\end{array}$ & $\begin{array}{l}\text { This study includes the } \\
\text { sample of 1981:1 to 2004:4. } \\
\text { Since the model is driven } \\
\text { by four shocks thus it is } \\
\text { estimated using data for } \\
\text { four series. The variables } \\
\text { are output in terms of real } \\
\text { domestic demand, } \\
\text { inflation, a short term } \\
\text { interest rate and real } \\
\text { money balances. }\end{array}$ & $\begin{array}{l}\text { This study uses slightly } \\
\text { different estimation strategy as } \\
\text { compared with others for } \\
\text { estimating DSGE models. For } \\
\text { example it points out that this } \\
\text { estimation shows an advantage } \\
\text { of estimating and forecasting for } \\
\text { the log levels of the data, rather } \\
\text { than forecasts for detrended } \\
\text { series. The method of estimation } \\
\text { is Maximum likelihood. It also } \\
\text { describes about the impulse } \\
\text { response drawn from the } \\
\text { estimates. }\end{array}$ & $\begin{array}{l}\text { Through this aspect of model } \\
\text { building study shows with sure that } \\
\text { the out of sample forecasts are } \\
\text { relatively more appealing than any } \\
\text { other model in comparison. For } \\
\text { some of the variables such as } \\
\text { interest rate and output in fact have } \\
\text { very good level of accuracy in } \\
\text { forecasting. The forecasting power } \\
\text { however for inflation is not so } \\
\text { strong yet it is not significantly less } \\
\text { than those of the benchmark VARs. } \\
\text { In the last this study introduces } \\
\text { several dimensions for } \\
\text { improvements in the model for } \\
\text { future work. }\end{array}$ \\
\hline 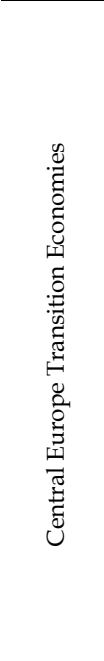 & $\begin{array}{l}\text { Sadeq, T. } \\
(2008)\end{array}$ & $\begin{array}{l}\text { This paper uses a small open } \\
\text { economy DSGE model for } \\
\text { central Europe Transition } \\
\text { economies, EU-15: Czech } \\
\text { Republic, Hungary, Poland, } \\
\text { Slovakia and Slovenia. The } \\
\text { objective is to analyze the } \\
\text { general model convergence } \\
\text { issues. }\end{array}$ & $\begin{array}{l}\text { Quarterly data for the } \\
\text { sample range 1996:2 to 2007:2 } \\
\text { has been used for empirical } \\
\text { analysis. Variables from each } \\
\text { country is selected. These } \\
\text { inlcude real GDP, household } \\
\text { consumption, nominal } \\
\text { wages, CPI Inflation, and } \\
\text { nominal short term interest } \\
\text { rates. }\end{array}$ & $\begin{array}{l}\text { This model is estimated by } \\
\text { utilizing the Bayesian } \\
\text { techniques utilizing information } \\
\text { from the previous studies as } \\
\text { priors. }\end{array}$ & $\begin{array}{l}\text { The estimation results of this } \\
\text { illustrate some differences from the } \\
\text { Euro area results in structural } \\
\text { parameters. However, the results } \\
\text { exhibit some similarities across } \\
\text { countries, notably in some shocks } \\
\text { volatilities and high habit formation } \\
\text { of consumption. The results } \\
\text { illustrate also an important degree } \\
\text { of rigidity of imported goods prices, } \\
\text { which implies a low pass-through of } \\
\text { the exchange rate fluctuations. } \\
\text { Finally, we study the Ramsey } \\
\text { optimal allocation, in a timeless } \\
\text { perspective, of the estimated model } \\
\text { for each country in order to analyze } \\
\text { the convergence criteria of entrance } \\
\text { in the European exchange rate } \\
\text { mechanism }\end{array}$ \\
\hline 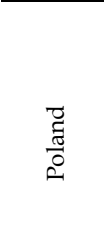 & $\begin{array}{l}\text { Kolasa, M. } \\
\text { (2008) }\end{array}$ & $\begin{array}{l}\text { This paper presents a two- } \\
\text { country model linking } \\
\text { Poland and the euro area }\end{array}$ & $\begin{array}{l}\text { The sample period is } 1997: 1 \\
\text { to } 2006: 4 \text {. The model uses } \\
\text { GDP growth, consumption, } \\
\text { CPI inflation, real wages, } \\
\text { investment, nominal } \\
\text { exchange rates and interest } \\
\text { rates variables. }\end{array}$ & $\begin{array}{l}\text { This open economy DSGE } \\
\text { framework is empirically } \\
\text { evaluated through calibrations } \\
\text { and estimated by the Bayesian } \\
\text { approach utilizing information } \\
\text { from the previous studies as } \\
\text { priors. }\end{array}$ & $\begin{array}{l}\text { Overall, results of this model can be } \\
\text { seen as rather inconclusive about } \\
\text { the differences in parameters } \\
\text { describing agent's decision-making } \\
\text { in Poland and in the euro area. }\end{array}$ \\
\hline
\end{tabular}




\begin{tabular}{|c|c|c|c|c|c|}
\hline $\begin{array}{l}\frac{\pi}{\pi} \\
\frac{\pi}{\pi} \\
\frac{\pi}{2}\end{array}$ & $\begin{array}{l}\text { Buncic and } \\
\text { Melecky } \\
(2008)\end{array}$ & $\begin{array}{l}\text { This paper provides an open } \\
\text { economy New Keynesian } \\
\text { policy model for Australian } \\
\text { economy. It focuses to } \\
\text { observe the importance of } \\
\text { external shocks on } \\
\text { macroeconomic fluctuations } \\
\text { as compared to the impact of } \\
\text { domestic shocks. }\end{array}$ & $\begin{array}{l}\text { For empirical purpose } \\
\text { quarterly data has been used } \\
\text { ranging from 1983/84:1 to } \\
\text { 2005:4. Variables are foreign } \\
\text { interest rate, the foreign } \\
\text { inflation, foreign output gap, } \\
\text { domestic interest rate, } \\
\text { domestic inflation,, domestic } \\
\text { output gap, real exchange } \\
\text { rate and nominal exchange } \\
\text { rate series. }\end{array}$ & $\begin{array}{l}\text { In the estimation section this } \\
\text { study mentions different } \\
\text { weaknesses of different } \\
\text { methods to estimate this } \\
\text { NKPM. Therefore, authors } \\
\text { prefer to estimate this model in } \\
\text { Bayesian framework. }\end{array}$ & $\begin{array}{l}\text { The empirical estimates suggest that } \\
\text { domestic and foreign demand } \\
\text { shocks and to some extent the } \\
\text { domestic supply shocks are the } \\
\text { most influential in Australian } \\
\text { business cycle. The effect of real } \\
\text { exchange rate on output is } \\
\text { somewhat mild. Inflation appears } \\
\text { very sensitive to the domestic } \\
\text { supply shocks. The impact of } \\
\text { domestic monetary policy however } \\
\text { on inflation is also mild. }\end{array}$ \\
\hline 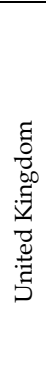 & $\begin{array}{l} \\
\text { DiCecio and } \\
\text { Nelson (2007) }\end{array}$ & $\begin{array}{l}\text { This study replicates the } \\
\text { DSGE model of Christiano, } \\
\text { Eichenbaum and Evans } \\
\text { (2005), in which both the } \\
\text { nominal frictions and } \\
\text { dynamics in preferences and } \\
\text { productions are incorporated. }\end{array}$ & $\begin{array}{l}\text { The sample period is 1979:2 } \\
\text { to 2005:4. Variables are UK } \\
\text { treasury bill rate, real GDP, } \\
\text { private household } \\
\text { consumption, gross fixed } \\
\text { capital formation, business } \\
\text { investment as an alternative } \\
\text { investment series, } \\
\text { productivity and inflation. }\end{array}$ & $\begin{array}{l}\text { In the first stage authors } \\
\text { estimate monetary policy shock } \\
\text { from a VAR and then use } \\
\text { minimum-distance estimation } \\
\text { procedures for estimating this } \\
\text { DSGE model. }\end{array}$ & $\begin{array}{l}\text { This study finds that the results are } \\
\text { consistent to policy regime changes. } \\
\text { These regime changes include shifts } \\
\text { in the role assigned to monetary } \\
\text { policy, for example policy changes } \\
\text { made investment decision more } \\
\text { closely based on the market forces. } \\
\text { It also shows that price stickiness is } \\
\text { more than wage stickiness as a } \\
\text { major source of nominal rigidity in } \\
\text { the UK. }\end{array}$ \\
\hline 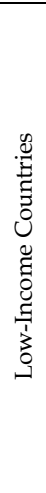 & $\begin{array}{l}\text { Peiris and } \\
\text { Saxegaard } \\
(2007)\end{array}$ & $\begin{array}{l}\text { This paper presents DSGE } \\
\text { model to evaluate monetary } \\
\text { policy tradeoffs in low- } \\
\text { income countries under } \\
\text { certain assumptions. The } \\
\text { model is estimated on data } \\
\text { for Mozambique in sub- } \\
\text { Sahara Africa except South } \\
\text { Africa. }\end{array}$ & $\begin{array}{l}\text { This model is estimated on } \\
\text { quarterly data covering the } \\
\text { period of 1996:1 to 2005:4. } \\
\text { Variable are GDP, } \\
\text { consumption, exports, } \\
\text { imports, the real exchange } \\
\text { rate, inflation, export price } \\
\text { inflation, import price } \\
\text { inflation, M2, currency in } \\
\text { circulation, deposit rates, } \\
\text { lending rates, foreign } \\
\text { currency reserves, } \\
\text { government spending, and } \\
\text { lending to the private sector. }\end{array}$ & $\begin{array}{l}\text { This DSGE framework is } \\
\text { empirically evaluated through } \\
\text { calibrations and estimated by } \\
\text { the Bayesian approach utilizing } \\
\text { information from the previous } \\
\text { studies as priors. }\end{array}$ & $\begin{array}{l}\text { This paper calls itself the first } \\
\text { attempt at estimating DSGE model } \\
\text { for SSA country and projects it as } \\
\text { the benchmark for low-income } \\
\text { countries. Results show that a } \\
\text { exchange rate peg is significantly } \\
\text { less successful than inflation } \\
\text { targeting at stabilizing the real } \\
\text { economy due to higher interest rate } \\
\text { volatility. }\end{array}$ \\
\hline 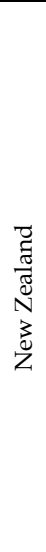 & Liu (2006) & $\begin{array}{l}\text { This study designs DSGE } \\
\text { based New Keynesian } \\
\text { framework to describe the } \\
\text { key features of a small open } \\
\text { economy. Particularly the } \\
\text { model focuses on the } \\
\text { transmission mechanism of } \\
\text { monetary policy to provide a } \\
\text { tool for basic policy } \\
\text { simulations. This model, } \\
\text { however, shows the capacity } \\
\text { to simulate the monetary } \\
\text { paths and to analyze the } \\
\text { policy outcome in } \\
\text { uncertainty. }\end{array}$ & $\begin{array}{l}\text { Data from 1991Q1 to 2004Q4 } \\
\text { for New Zealand is used. } \\
\text { Key variables are GDP, } \\
\text { overall inflation, import } \\
\text { inflation, nominal interest } \\
\text { rate, competitive price index, } \\
\text { real exchange rate, foreign } \\
\text { output, and foreign real } \\
\text { interest rate. }\end{array}$ & $\begin{array}{l}\text { Similar to many other empirical } \\
\text { studies Liu (2006) estimates the } \\
\text { DSGE for small open economy } \\
\text { in Bayesian framework. This } \\
\text { method provides comparison } \\
\text { between non-nested models and } \\
\text { parameter uncertainty } \\
\text { explicitly. The Bayesian } \\
\text { inferences are in terms of } \\
\text { probabilistic statements rather } \\
\text { than the notional repeated } \\
\text { samples of classical hypothesis } \\
\text { testing procedures. }\end{array}$ & $\begin{array}{l}\text { The main empirical findings are; a) } \\
\text { the intertemporal consumption } \\
\text { substitutability is very little which } \\
\text { implies that the New Zealand does } \\
\text { not produce close substitutes of the } \\
\text { foreign goods. b) Immobile labor } \\
\text { force is backed by the low elasticity } \\
\text { of labor supply decisions. c) Price } \\
\text { contracts were estimated around } \\
\text { four quarters for import retailers } \\
\text { and five quarters for domestic } \\
\text { producers. e) Impulse response } \\
\text { functions depict the dynamic } \\
\text { behavior of shocks and the } \\
\text { monetary transmission mechanism } \\
\text { for the rest of economy. }\end{array}$ \\
\hline
\end{tabular}




\begin{tabular}{ll}
\hline & This paper presents a small \\
open economy DSGE model \\
for Barazilian economy with \\
special reference to monetary \\
policy analysis. A distinctive \\
feature of the model is that \\
the terms of trade enters \\
directly into the new \\
Ka Silveira, \\
K. A. C. & $\begin{array}{l}\text { neynesian Phillips curve as a } \\
\text { feeding theinflation, so that } \\
\text { there is no more the direct } \\
\text { relationship between } \\
\text { marginal cost and output } \\
\text { gapthat characterizes the } \\
\text { closed economies. }\end{array}$
\end{tabular}

This model is estimated on quarterly data of the

Barzilian and U.S. economies for the periods from 1999 Q3 to 2005 Q3. Variables included real GDP, CPI Inflation, 3 month T. Bill Real Exchange Rate as a proxy of short term interest rates, Term of Trade, U.S real per capita GDP and U.S. CPI Inflation.
This small open economy DSGE The empirical part of the paper framework is empirically yields promising qualitative results. evaluated through calibrations The main empirical findings are: (i) and estimated by the Bayesian a higher TOT improves its external approach utilizing information competitiveness, shiftingthe world from the previous studies as demand towards its goods. The consequent higher output heats the labor market, pushing the real wage and marginal cost up. (ii) Ceteris paribus, a higher TOT increases the real wage and marginal cost in terms of the domestic goods, leading each firm to adjust its nominal price up in order to increase its relative price - in terms of the other domestic good - and thereby preserve their markup.

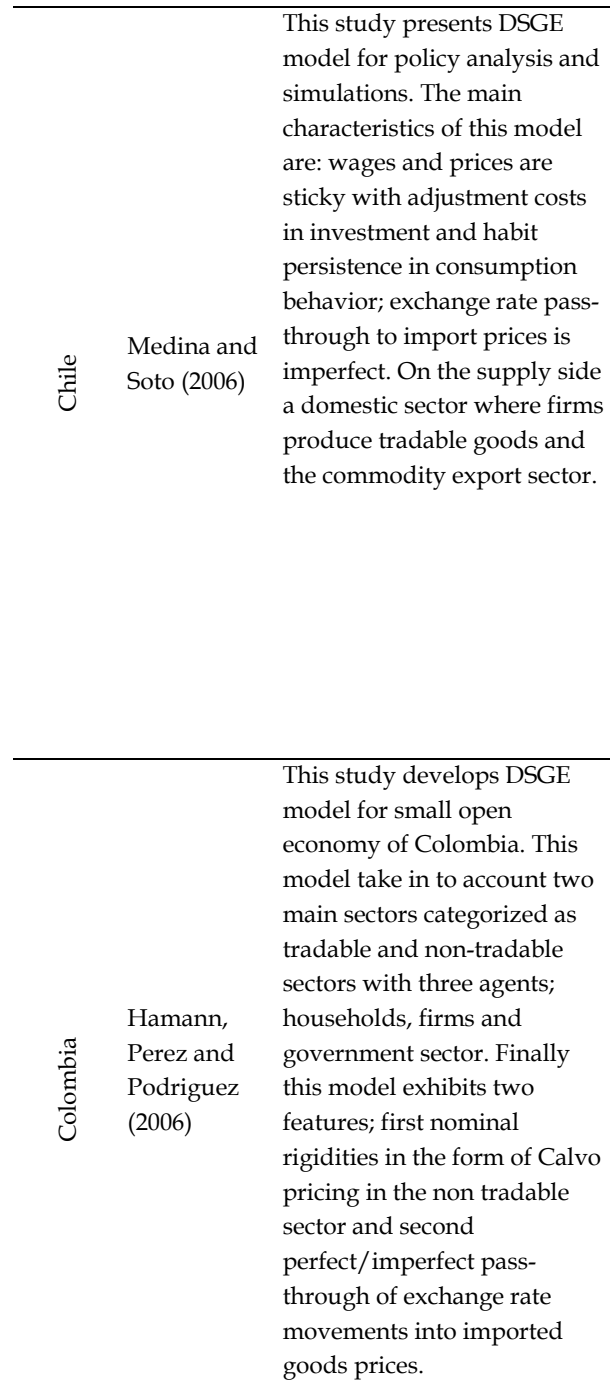

Quarterly data for the period The Bayesian methodology is of 1990: 1 to 2005: 4 has been used. Variables include real GDP, consumption, investment, exports; commodity production by using natural-resources based GDP as a proxy, short run real interest rates, a measure of core inflation as a corresponding density function. proxy for inflation, the real exchange rate, nominal devaluation, and real wages. It also include real foreign GDP, foreign inflation weighted average of inflation in trade partners, foreign interest rate and the international price of copper deflated by the foreign price index.

Quarterly data with the
range of 1987:1 to 2005:4 has been used in estimation. The variables are inflation, nominal interest rate, and real output and exchange rate. These variables are transformed according to the characteristics of the model. applied to jointly estimate the parameters of this DSGE model. This study takes into account the information of Priors from the earlier empirical studies for Chile, or imposes diffuse Priors by setting a relatively large standard deviation for the By using the estimated Posteriors this study provides analysis of impulse-response for a shock to the exported commodity good, foreign output and a monetary shock.

rout and a monetary shock.

Wages are optimally set with the span of eight years while the prices of domestic goods take several years. Prices of imported goods take three quarters. Results also depict the habit persistence in consumption and adjustment costs in investment are the relevant features. Impulse-response shows that a commodity price shock generates soft consumption and investment booms and a GDP expansion. It also shows a real exchange rate appreciation lowers inflation and reduces employment. It depicts that a monetary policy shock generates positive responses of GDP, consumption and investment, and a fall in inflation.

\author{
In this study three methods are This model show that the policy \\ reviewed and used in shocks explain only 3.7 percent \\ estimating the DSGE model. variation in inflation, 2.2 percent in \\ These methods are Calibration, real exchange rate and just 0.1 \\ Minimum Distance Spectral \\ Analysis and the Bayesian \\ technique. \\ percent in output. The largest \\ source of variation comes from the \\ shocks in the TFP of the non-traded \\ sector. Foreign shocks are also taken \\ into account, terms of trade account \\ for 62 percent in the variation of real \\ exchange rate and about third of \\ volatility in output, interest rates \\ and inflation. It is also discussed \\ that the DSGE model outcome does \\ not show good degree of forecasting \\ ability as compared with MTYNO.
}




\begin{tabular}{|c|c|c|c|c|c|}
\hline 莺 & Tovar (2006) & $\begin{array}{l}\text { This study is focused on the } \\
\text { analysis of effects of currency } \\
\text { devaluations on output in } \\
\text { Chile, Colombia and Mexico } \\
\text { using an estimated DSGE } \\
\text { model. This study also } \\
\text { provides comparison across } \\
\text { these three economies by } \\
\text { utilizing the estimated } \\
\text { parameters. }\end{array}$ & $\begin{array}{l}\text { Seasonally adjusted } \\
\text { quarterly series have been } \\
\text { used with the range from } \\
\text { 1989:1 to 2005:4. The } \\
\text { variables are inflation, } \\
\text { output, labor, private } \\
\text { consumption, changes of the } \\
\text { nominal exchange rate, } \\
\text { interest rate, and the level of } \\
\text { nominal exchange rate. }\end{array}$ & $\begin{array}{l}\text { This DSGE model is estimated } \\
\text { by the Maximum Likelihood } \\
\text { method. This study claims that } \\
\text { this method is optimal in } \\
\text { estimating DSGE model for } \\
\text { small open economy. } \\
\text { Estimation through this } \\
\text { technique however creates } \\
\text { problem of stochastic } \\
\text { singularity. Therefore, } \\
\text { additional shocks were created } \\
\text { to address this problem. In the } \\
\text { second stage estimation is done } \\
\text { by introducing measurement } \\
\text { errors. }\end{array}$ & $\begin{array}{l}\text { The estimates and the impulse- } \\
\text { response analysis shows that during } \\
\text { the last two decades devolutionary } \\
\text { policy shocks have been on average } \\
\text { expansionary in terms of output. It } \\
\text { also depict that contractionary } \\
\text { balance sheet transmission } \\
\text { mechanism has been dominated by } \\
\text { the expenditure-switching effect. } \\
\text { While the balance sheet } \\
\text { transmission mechanism has been } \\
\text { weaker in Mexico than in Chile and } \\
\text { Colombia. }\end{array}$ \\
\hline 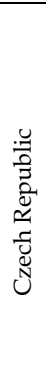 & $\begin{array}{l}\text { Benes, Hledik } \\
\text { and Vavra } \\
(2005)\end{array}$ & $\begin{array}{l}\text { This is a small open economy } \\
\text { DSGE model. The } \\
\text { characteristics of this model } \\
\text { are so broad with the } \\
\text { innovative features. These are } \\
\text { international currency } \\
\text { pricing scheme permitting } \\
\text { flexible calibration of import } \\
\text { and export price elasticities } \\
\text { along with the disconnect of } \\
\text { nominal exchange rate. }\end{array}$ & $\begin{array}{l}\text { This paper uses quarterly } \\
\text { data with the sample range } \\
\text { 1996:1 to 2004:4 for Czech } \\
\text { economy. The main variables } \\
\text { are GDP, import prices, } \\
\text { export prices, investment, } \\
\text { labor, consumption } \\
\text { expenditures, labor } \\
\text { participation, wage rate, } \\
\text { exchange rate, interest rate, } \\
\text { and inflation. }\end{array}$ & $\begin{array}{l}\text { The empirical analysis of this } \\
\text { DSGE model is presented in } \\
\text { terms of calibration strategy and } \\
\text { impulse-response setup. }\end{array}$ & $\begin{array}{l}\text { This model policy reaction with a } \\
\text { parameterized forecast horizon and } \\
\text { a generalized capital accumulation } \\
\text { equation with imperfect } \\
\text { intertemporal substitution of } \\
\text { investment provide useful forecast } \\
\text { of Czech Republic monetary policy } \\
\text { decision variables. }\end{array}$ \\
\hline 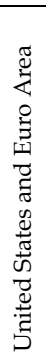 & $\begin{array}{l}\text { Negro, } \\
\text { Schorfheide, } \\
\text { Smets and } \\
\text { Wouters } \\
(2005)\end{array}$ & $\begin{array}{l}\text { This paper presents the } \\
\text { modified version of DSGE } \\
\text { model for Euro area. This } \\
\text { model introduces stochastic } \\
\text { trends so that it can be fitted } \\
\text { to unfiltered time series } \\
\text { observations. It contains a } \\
\text { large number of nominal and } \\
\text { real frictions and various } \\
\text { structural shocks. }\end{array}$ & $\begin{array}{l}\text { Quarterly data for the } \\
\text { sample range 1986:1 to 2002:4 } \\
\text { has been used for empirical } \\
\text { analysis. Variables are GDP } \\
\text { per capita, investment, } \\
\text { hourly nominal wages, GDP } \\
\text { deflator, M2 per capita, and } \\
\text { nominal short term interest } \\
\text { rates. }\end{array}$ & $\begin{array}{l}\text { This DSGE model is estimated } \\
\text { by applying the VAR } \\
\text { framework. }\end{array}$ & $\begin{array}{l}\text { This study instead of some focused } \\
\text { conclusion provides some choices of } \\
\text { inferences by showing comparisons } \\
\text { of the values of priors. }\end{array}$ \\
\hline 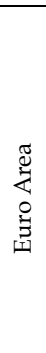 & $\begin{array}{l}\text { Wouters and } \\
\text { Smets (2003) }\end{array}$ & $\begin{array}{l}\text { Authors develop the DSGE } \\
\text { model with stick prices and } \\
\text { wages for the euro area. This } \\
\text { model includes many other } \\
\text { features such as habit } \\
\text { formation, costs of } \\
\text { adjustment in capital } \\
\text { accumulation and the } \\
\text { variable of capacity } \\
\text { utilization. }\end{array}$ & $\begin{array}{l}\text { The key variables used in } \\
\text { this study are GDP, } \\
\text { consumption, investment, } \\
\text { prices, real wages, } \\
\text { employment and the } \\
\text { nominal interest. }\end{array}$ & $\begin{array}{l}\text { This model is estimated by } \\
\text { utilizing the Bayesian } \\
\text { techniques. As a part of the } \\
\text { empirical strategy study } \\
\text { quantifies the structural shocks } \\
\text { and their contribution to } \\
\text { business cycle fluctuations. }\end{array}$ & $\begin{array}{l}\text { This study suggested that there is } \\
\text { large degree of price and wage } \\
\text { stickiness in the euro area. Model } \\
\text { based output and interest rate gap } \\
\text { show a considerable uncertainty } \\
\text { around it. There is not observed the } \\
\text { liquidity impact and expectations } \\
\text { take time to adjust and the output } \\
\text { effects are much smaller. }\end{array}$ \\
\hline
\end{tabular}




\section{References}

[1]. Adolfson, M., S. Laséen, J. Linde, and M. Villani (2008). “Evaluating an estimated new Keynesian small open economy model", Journal of Economic Dynamics and Control, 32: 2690-2721

[2]. Adolfson, M., S. Laséen, J. Linde, and M. Villani (2007a). "RAMSES: a new general equilibrium model for monetary policy analysis", Risksbank, Economic Review, Vol. 2.

[3]. Adolfson, M., S. Laséen, J. Linde, and M. Villani (2007b). "Bayesian estimation of an open economy DSGE model with incomplete pass-through", Journal of International Economics, 72: 481-511

[4]. Altug, S. (1989). “Time-to-Build and Aggregate Fluctuations: Some New Evidence”, International Economic Review, 30: 889-920

[5]. An, S., and F. Schorfheide (2007). “Bayesian analysis of DSGE models”, Econometric Reviews, 26: 113-172

[6]. Benes, J., T. Hledik, M. Kumhof and D. Vavra (2005). "An Economy in Transition and DSGE: What the Czech National Bank's New Projection Model Needs", Czech National Bank, Research Department, Working Papers 2005/12

[7]. Bosch, M. (2007). "Job Creation and Job Destruction in the Presence of Informal Labour Markets", Mimeo, London School of Economics.

[8]. Brubakk, L, T. Anders, J. Maih, K. Olsen and M. Østnor (2006). "Finding NEMO: Documentation of the Norwegian economy model", Norwegian Central Bank, Staff Memo No. 2006-6.

[9]. Bukhari, S. A. H. A. S. and S. U. Khan (2008). “Estimating Output Gap for Pakistan Economy: Structural and Statistical Approaches", State Bank of Pakistan, Working Paper Series No. 24

[10]. Buncic, D. and M. Melecky (2008). "An Estimated New Keynesian Policy Model for Australia", The Economic Record, The Economic Society of Australia, 84: 1-16

[11]. Calvo, G. A. (1983). "Staggered price setting in a utility-maximizing framework", Journal of Monetary Economics, 12: 383-398

[12]. Canova, F. (2002). "Validating two monetary models via VARs", CEPR working 3442

[13]. Canova, F. (2007). "Methods for applied macroeconomic research", Princeton University Press.

[14]. Castillo, P., C. Montoro and V. Tuesta (2008). "MEGA-D: Modelo de equilibrio general aggregado con dolarización parcial para la economía peruana", Central Reserve Bank of Peru, forthcoming.

[15]. Chisti, U. S. A. Hasan, and S. F. Mahmud (1992), “Macroeconometric modeling and Pakistan's Economy: A vector autoregression approach", Journal of Development Economics, 38: 353-370

[16]. Christiano, L., and M. Eichenbaum (1992). "Current Real-Business Cycle Theories and Aggregate LaborMarket Fluctuations", American Economic Review, 82: 430-45

[17]. Christiano, L. J., M. Eichenbaum, and C. L. Evans (1997). "Sticky price and limited participation models of money: A comparison", European Economic Review, 41: 1201-1249

[18]. Christiano, L. J., M. Eichenbaum, and C. L. Evans (1998). "Monetary policy shocks: What have we learned and to what end?", In Taylor, J. B. and M. Woodford (Eds.), Handbook of Macroeconomics. Amsterdam, NorthHolland.

[19]. Christiano, L., M. Eichembaum and C. Evans (2005). "Nominal rigidities and the dynamic effects to a shock of monetary policy", Journal of Political Economy, 113: 1-45

[20]. Christoffel, K., Günter C. and Anders W. (2008). "NAWM: A Micro-Founded Open-Economy Model for Forecasting and Policy Analysis", ECB Working Paper No. 944 / October 2008.

[21]. Clarida, R. and M. Gertler, (1997). "How the Bundesbank conducts monetary policy", Memo, Bundesbank.

[22]. Clarida, R., J. Gali and M. Gertler, (1998). "Monetary policy rules in practice: Some international evidence", European Economic Review, 42: 1033-1067

[23]. Clarida, R., J. Gali and M. Gertler, (1999). "The science of monetary policy: A new Keynesian perspective", Journal of Economic Literature, 37: 1661-1707

[24]. Clarida, R., J. Gali and M. Gertler, (2000), “Monetary policy rules and macroeconomic stability: Evidence and some theory", Quarterly Journal of Economics, 115: 147-180

[25]. Colander, D., P. Howwit, A. Kirman, A. Leijonhufvud and P. Mehrling (2008). "Beyond DSGE models: toward an empirically based macroeconomics", American Economic Review: Papers and Proceedings, 98: 236240

[26]. Copaciu, M. F. Neagu , H. Braun-Erdei (2005). "Survey Evidence on Price Setting Patterns of Romanian Firms", Mimeo, National Bank of Romania 
[27]. da Silveira, M. A. C. (2006). “A Small Open Economy as a Limit Case of a Two-Country New Keynesian DSGE Model: A Bayesian Estimation with Brazilian Data", Instituto de Pesquisa Econômica Aplicada, Discussion Paper no 1252a

[28]. DeJong, D., B. Ingram, and C. Whiteman (2000). "A Bayesian Approach to Dynamic Macroeconomics", Journal of Econometrics, 98: 201-223

[29]. Dib, A., M. Gammoudi, and K. Moran (2005). "Forecasting with the New-Keynesian Model: An Experiment with Canadian Data", manuscript, Bank of Canada

[30]. Dib, A. \& M. Gammoudi and K. Moran (2008). "Forecasting Canadian time series with the New Keynesian model", Canadian Journal of Economics, Canadian Economics Association, 41: 138-165

[31]. DiCecio, R. and Edward Nelson, (2007). "An estimated DSGE model for the United Kingdom", Review, Federal Reserve Bank of St. Louis, July Issue, 215-232

[32]. Diebold, F. X. (1998). “The Past, Present, and Future of Macroeconomic Forecasting", Journal of Economic Perspectives, 12: 175-192

[33]. Dixit, A., and J. Stiglitz (1977). "Monopolistic Competition and Optimum Product Diversity", American Economic Review, 67: 297-30

[34]. Eichenbaum, M. and C. Evans (1995). "Some empirical evidence on the effects of shocks to monetary policy on exchange rates", Quarterly Journal of Economics, 110: 975- 1010

[35]. Erceg, C., L. Guerrieri and C. Gust (2006). "SIGMA: a new open economy model for policy analysis", International Journal of Central Banking, 2: 111-144

[36]. Fama, E. (1984). "Forward and spot exchange rates", Journal of Monetary Economics, 14: 319- 338

[37]. Faust, J. and J. Rogers (2003). "Monetary policy's role in exchange rate behavior", Journal of Monetary

[38]. Economics, 50: 1403- 1424

[39]. Favero, C. (2001). "Applied macroeconometrics", Oxford University press.

[40]. Froot, K. and J. Frankel (1989). "Forward discount bias: is it an exchange risk premium", Quarterly Journal of Economics, 104: 139- 161

[41]. Gali, J. (2008). "Monetary Policy, Inflation and the Business Cycle: An introduction to the New Keynesian Framework", Princeton University Press

[42]. Gali, J. and M. Gertler, (1999). "Inflation dynamics: A structural econometric analysis", Journal of Monetary Economics, 44: 195-222

[43]. Gali, J., and M. Gertler (2007). "Macroeconomic modeling for monetary policy evaluation", Journal of Economic Perspectives, 21, Fall Issue

[44]. Gali, J., T. Monacelli (2005). "Monetary Policy and Exchange Rate Volatility in a Small Open Economy" Review of Economic Studies, 72: 707-734

[45]. Gelman, A., J. B. Carlin, H. S. Stern and D. B. Rubin (2006). "Bayesian Data Analysis", Second Edition, Text in Statistical Science, Chapman and Hall

[46]. Geweke, J. (1995). "Monte Carlo Simulation and Numerical Integration”, Federal Reserve Bank of Mineapolis, Research Department Staff Report 192.

[47]. Geweke, J. (1999). “Using Simulation Methods for Bayesian Econometric Models: Inference, Development and Communication," Econometric Reviews, 18: 1-73

[48]. Goodfriend, M. (2007). "How the world achieved consensus on monetary policy", Journal of Economic Perspectives, 21, Fall Issue

[49]. Goodfriend, M. and R. King (1997). "The new neoclassical synthesis and the role of monetary policy", NBER Macroeconomics Annual, Vol. 1997.

[50]. Gouvea, S., A. Minella, R. Santos, and N. Souza-Sobrinhoy (2008). “Samba: Stochastic Analytical Model with a Bayesian Approach", Workshop Paper, Central Bank Workshop on Macroeconomic Modeling 2008, Banco de la República, Colombia.

[51]. Griffolio, T. M. (2007). "DYNARE user manual: An introduction to the solution and estimation of DSGE models", Unpublished Manuscript.

[52]. Hamann, F., J. Pérez and D. Rodríguez (2006). "Bringing a DSGE model into policy environment in Colombia", Conference Paper, Central Bank of Chile

[53]. Harrison, R., K. Nikolov, M. Quinn, G. Ramsay, A. Scott and R. Thomas (2005). “Bank of England Quarterly Model", Bank of England.

[54]. Haque, N. U. \& A. M. Husain, \& P. J. Montiel (1994). "An empirical "dependent economy" model for Pakistan", World Development, 22: 1585-1597

[55]. Hastings, W. (1970). "Monte Carlo sampling methods using Markov Chains and their applications" Biometrika, 57: 97-109 
[56]. Ireland, P. N. (2000a). "Sticky-Price Models of the Business Cycle: Specification and Stability", NBER Working Paper 7511

[57]. Ireland, P. N. (2000b). "Sticky-Price Models of the Business Cycle: Specification and Stability," NBER Working Paper 7511.

[58]. Ireland, P. N. (2004). “Technology Shocks in the New Keynesian Model”, NBER Working Paper No. W10309

[59]. Justiniano, A., B. Preston (2004). "Small open economy DSGE models: specification, estimation and model fit", Manuscript, Columbia University.

[60]. Justiniano, A., B. Preston (2005). “Can structural small open economy models account for the influence of foreign shocks", Manuscript, Columbia University.

[61]. Kemal, A. R. and M. F. Arby (2004). "Quarterization of annual GDP of Pakistan", Statistical paper series 05, Pakistan Institute of Development Economics, Islamabad

[62]. Keynes, J. M. (1936). "The General Theory of Employment, Interest and Money", Harcourt Brace Jovanovich.

[63]. Kim, J. (2000). "Constructing and Estimating a Realistic Optimizing Model of Monetary," Journal of Monetary Economics, 45: 329-359

[64]. Klein, P (2000). "Using the generalized Schur form to solve a multivariate linear rational expectations model", Journal of Economic Dynamics \& Control, 24: 1405-1423

[65]. Kolasa, M. (2008). "Structural heterogeneity or asymmetric shocks? Poland and the euro area through the lens of a two-country DSGE model", National Bank of Poland, Working Paper No. 49

[66]. Koop, G., D. J. Poirier and J. L. Tobias (2007). "Bayesian Econometric Methods", Cambridge University Press

[67]. Kwapil, C., J. Baumgartner and J. Scharler (2005). "The Price-Setting Behavior of Austrian Firms Some Survey Evidence", European Central Bank, Working Paper Series No. 464

[68]. Kydland, F. E., and E. C. Prescott (1982). "Time to build and aggregate fluctuations", Econometrica, 50: 13451370

[69]. Kydland, F. E. and E. C. Prescott (1996). "The computational experiment: an econometric tool", Journal of Economic Perspectives, 10, Winter Issue.

[70]. $\quad$ Lancaster, T. (2004). "An introduction to modern Bayesian econometrics", Blackwell publishing.

[71]. Laforte, J. P. (2004). "Comparing Monetary Policy Rules in an Estimated General Equilibrium Model of the U.S. Economy", Memo, Federal Reserve Board of Governors.

[72]. Landon-Lane, J. (1998). "Bayesian Comparison of Dynamic Macroeconomic Models," Ph.D. Dissertation, University of Minnesota

[73]. Laxton, D. (2008). "Getting to know the Global Economy Model and its philosophy", IMF Staff Papers, 55: 213-242

[74]. Leeper, E., and C. Sims (1994). "Toward a Modern Macroeconomic Model Usable for Policy Analysis" in Stanley Fischer and Julio Rotemberg (eds) NBER Macroeconomics Annual, MIT Press, Cambridge, MA.

[75]. Liu, P. (2006). "A Small New Keynesian Model of the New Zealand economy", Reserve Bank of New Zealand, Discussion Paper Series, No. 03/06

[76]. Lubik, T., Schorfheide, F. (2005). "A Bayesian look at new open economy macroeconomics". In: Gertler, M., Rogoff, K. (Eds.), NBER Macroeconomics Annual, 313- 336

[77]. Lucas, J. R. (1976). “Econometric policy evaluation: a critique", in K. Brunner and A Meltzer, The Phillips curve and labor markets, North Holland.

[78]. Lucas, J. R. and Sargent, T. J. (1979). "After Keynesian Macroeconomics", Federal Reserve Bank of Minneapolis, Quarterly Review, 3: 1-16

[79]. Malik, W. S. and A. M. Ahmed (2007). "The Taylor Rule and the Macroeconomic Performance in Pakistan, Pakistan Institute of Development Economics, Working Paper Series No. 2007:34, Islamabad, Pakistan

[80]. Mankiw, G. N. (1985). "Small menu costs and large business cycles: A macroeconomic model of monopoly", Quarterly Journal of Economics, 100: 529-539

[81]. Mankiw, G. N. (1989). "Real business cycle: A new Keynesian perspective", Journal of Economic Perspectives, 3: 79-90

[82]. Mankiw, G. N. (1990). “A quick refresher course in macroeconomics”, Journal of Economic Literature, 28: 16451660

[83]. Mankiw, G. N. and D. Romer, (1990). "New Keynesian Economics", MIT, Press, Boston.

[84]. Mankiw, G. N. (2006). "The macroeconomist as scientist and engineer", Journal of Economic Perspectives, fall issue, 20: 29-461

[85]. McCarthy, F. D. and L. Taylor (1980). "Macro Food Policy Planning: a General Equilibrium Model for Pakistan", Review of Economics and Statistics, 62: 107-121 
[86]. McGrattan, E. (1994). “The Macroeconomic Effects of Distortionary Taxation," Journal of Monetary Economics, 33: 573-601

[87]. Medina, J. P. and C. Soto. (2006). "Model for Analysis and Simulations: A Small Open Economy DSGE for Chile", Conference Paper, Central Bank of Chile

[88]. Medina, J. and C. Soto (2007). "The Chilean business cycle through the lens of a stochastic general equilibrium model", Central Bank of Chile, Working Papers No. 457

[89]. Monacelli, T. (2003). "Monetary Policy in a Low Pass-through Environment", European Central Bank, Working Paper No. 227

[90]. Murchison, S. and A. Rennison (2006). "ToTEM: The Bank of Canada's new quarterly projection model", Bank of Canada, Technical Report No. 97.

[91]. Naqvi S. N. H., A. M. Ahmed and et al. (1983). "The PIDE Macroeconometric Model of Pakistan's Economy", Pakistan Institute of Development Economics, Islamabad, Pakistan

[92]. Naqvi S. N. H., A. M. Ahmed (1986). "Preliminary Revised P.I.D.E. Macro-econometric Model of Pakistan's Economy", Pakistan Institute of Development Economics, Islamabad, Pakistan.

[93]. Negro, M. D., F. Schorfheide, F. Smets and R. Wouters (2005). "On the fit and forecasting performance of NewKeynesian models", European Central Bank, Working Paper Series 491

[94]. Obstfeld, M. and K. Rogoff (2002). "New directions for stochastic open economy models", Journal of International Economics, 50, 117-153

[95]. Omer, M. and O. F. Saqib (2008). "Monetary Targeting in Pakistan: A Skeptical Note", State Bank of Pakistan, Working Paper Series No. 25

[96]. Onatski, A., and N. Williams (2004). "Empirical and Policy Performance of a Forward-Looking Monetary Model", mimeo, Princeton University.

[97]. Otrok, C. (2001). "On Measuring the Welfare Cost of Business Cycles", Journal of Monetary Economics, 47: 6192

[98]. Pasha, H. A., M. A. Hasan, A. G. Pasha, Z. H. Ismail, A. Rasheed, M. A. Iqbal, R. Ghaus, A. R. Khan, N. Ahmed, N. Bano and N. Hanif (1995), "Integrated Social Policy and Macro-Economic Planning Model for Pakistan", Social Policy and Development Center, Karachi, Pakistan, Research Report, No. 7

[99]. Peiris, S. J. and M. Saxegaard (2007). “An Estimated DSGE Model for Monetary Policy Analysis in Low-Income Countries", IMF Working Paper No. 07/282

[100]. Pesenti, E. (2008). "The Global Economy Model: theoretical framework", IMF Staff Papers, 55, 243-284

[101]. Prescott, E. (1986). "Theory ahead of business cycle measurement", Federal Reserve Bank of Minneapolis, Quarterly Review, Fall, 9-22

[102]. Ratto, M., W. Roeger, J. in 't Veld (2008). “QUEST III: An estimated open-economy DSGE model of the euro area with fiscal and monetary policy", Economic Modeling, Forthcoming Issue

[103]. Ratto, M. (2007). “Analyzing DSGE models with Global Sensitivity Analysis", Computational Economics, 31, $115-139$

[104]. Romer, C. and D. Romer (1997), "Reducing inflation", NBER and University of Chicago Press.

[105]. Romer, D. (1993). "The New Keynesian Synthesis", Journal of Economic Perspectives, American Economic Association, 7: 5-22

[106]. Romer, D. (2006). “Advanced Macroeconomics". Third Edition, McGraw-Hill, New York.

[107]. Ruge-Murcia, F. (2003). "Methods to Estimate Dynamic Stochastic General Equilibrium Models", Cahier 172003.

[108]. Sadeq, T. (2008). "Bayesian estimation of a DSGE model and optimal monetary policy for central Europe transition countries", Memo, EPEE, Université d.Evry Val d.Essonne

[109]. Sargent, T. J., and N. Wallace (1975). "Rational expectations, the optimal monetary instrument, and the optimal money supply rule", Journal of Political Economy, 83: 241-254.

[110]. Schmidtt-Grohé, S. and M. Uribe (2003). "Closing small open economy models", Journal of International Economics, 61: 163-185

[111]. Schorfheide, F. (2000). "Loss Function Based Evaluation of DSGE Models", Journal of Applied Econometrics, 15: 645-670

[112]. Siddiqui, R. and Z. Iqbal (1999). "Social Accounting Matrix of Pakistan for 1989-90", PIDE, Islamabad, Research Report Series No. 171

[113]. Siddiqui, R. and Z. Iqbal (2001). "Tariff Reduction and Functional Income Distribution in Pakistan: A CGE Approach", MIMAP Technical Paper Series, No. 10, PIDE, Islamabad, Pakistan 
[114]. Siddiqui, R. and A. R. Kemal (2006). "Poverty-Reducing or Poverty-Inducing? A CGE-based Analysis of Foreign Capital Inflow in Pakistan", PIDE Working Paper No. 2, PIDE, Islamabad, Pakistan

[115]. Sims, C. (1996). "Macroeconomics and Methodology", Journal of Economic Perspectives, 10: 105-120

[116]. Sims, C. (2002). "Solving Linear Rational Expectations Models", Computational Economics, 20: 1-20

[117]. Smets, F., and R. Wouters (2003). "Monetary Policy in an Estimated Stochastic Dynamic General Equilibrium Model of the Euro Area", Journal of the European Economic Association, 1: 1123-1175

[118]. Taylor, J. B. (1980). "Aggregate dynamics and staggered contracts", Journal of Political Economy, 88: 1-23

[119]. Taylor, J. (1993). "Discretion versus Policy Rules in Practice", Carnegie-Rochester Series on Public Policy, 39, 195- 214, North-Holland, Amsterdam

[120]. Taylor, J. B. (1998). "Staggered price and wage setting in macroeconomics". In Taylor, J. B. and M. Woodford (Eds.), Handbook of Macroeconomics, Amsterdam, North-Holland.

[121]. Taylor, J. B. (1999). "Monetary policy rules, Chicago", NBER and University of Chicago Press.

[122]. Tovar, E. C. (2005). "The mechanics of devaluations and the output response in a DSGE model: how relevant is the balance sheet effect?", Bank for International Settlements, BIS Working Papers No. 192.

[123]. Tovar, E. C. (2008). "DSGE models and central Banks", Bank for International Settlements, BIS Working Paper No. 258.

[124]. Uhlig, H. (1999). "A Toolkit for Analyzing Nonlinear Dynamic Stochastic Models Easily" in Ramon Marimom and Adrian Scott, (Eds) Computational Methods for the Study of Dynamic Economies, Oxford University Press.

[125]. Woodford, M. (2004). "Interest and Prices: Foundations of a Theory of Monetary Policy", Princeton University Press

[126]. Yun, T. (1996). “Nominal price rigidity, money supply endogeneity and business cycle”, Journal of Monetary Economics, 37: 345-370 